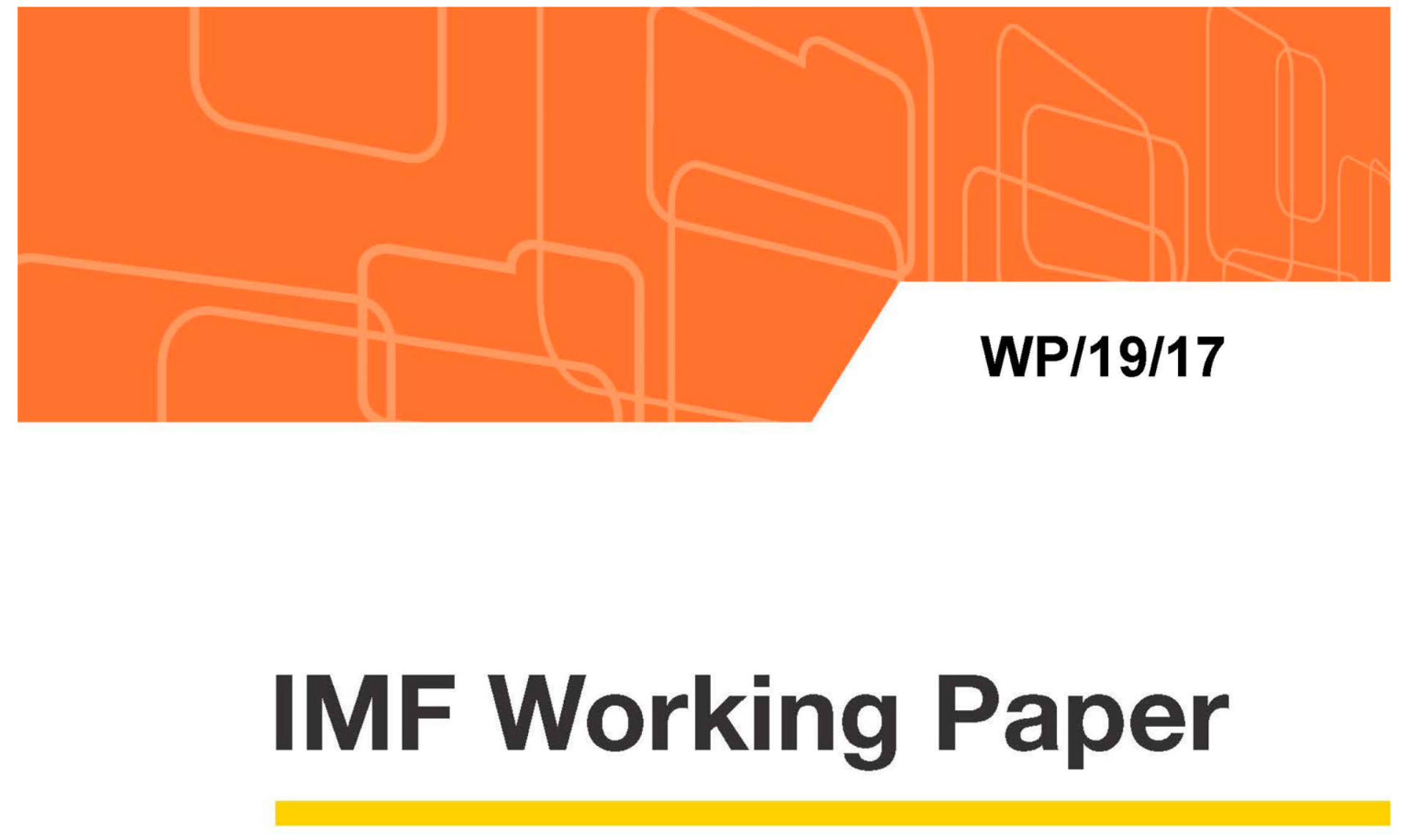

\title{
Innovation and Corporate Cash Holdings in the Era of Globalization
}

\author{
Konrad Adler, JaeBin Ahn, Mai Chi Dao
}

IMF Working Papers describe research in progress by the author(s) and are published to elicit comments and to encourage debate. The views expressed in IMF Working Papers are those of the author(s) and do not necessarily represent the views of the IMF, its Executive Board, or IMF management. 


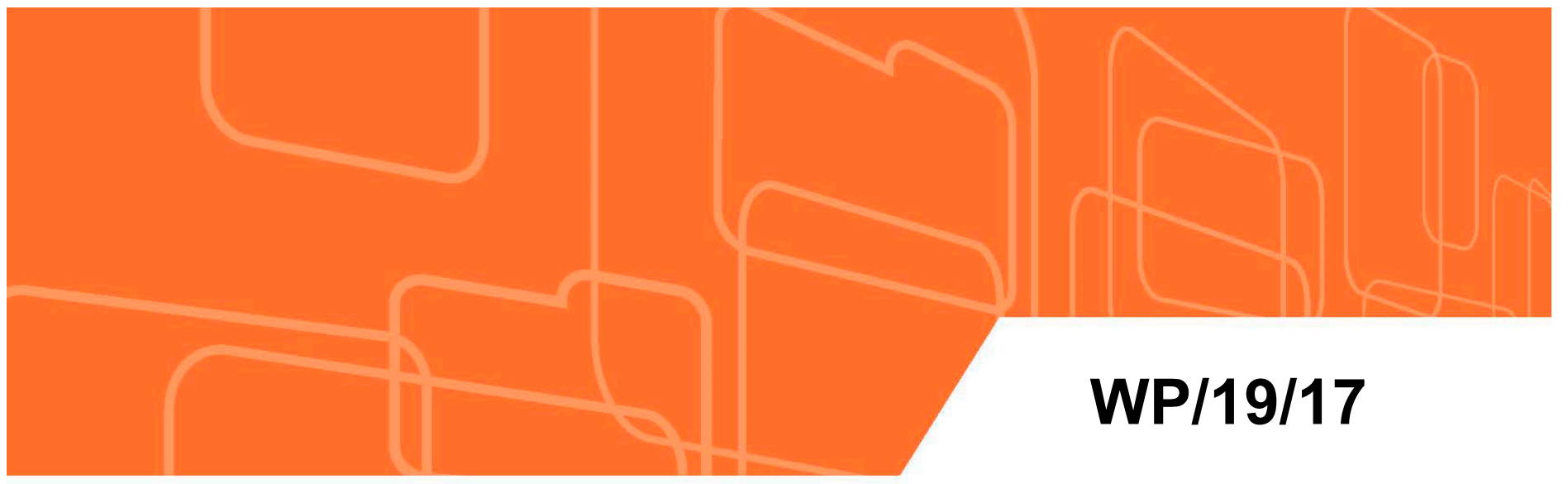

\section{IMF Working Paper}

\section{Innovation and Corporate Cash Holdings in the Era of} Globalization

Konrad Adler, JaeBin Ahn, Mai Chi Dao

IMF Working Papers describe research in progress by the author(s) and are published to elicit comments and to encourage debate. The views expressed in IMF Working Papers are those of the author(s) and do not necessarily represent the views of the IMF, its Executive Board, or IMF management.

I N T E R N A T I O N A L M O N E T A R Y F U N D 


\title{
IMF Working Paper
}

\author{
Research Department
}

\author{
Innovation and Corporate Cash Holdings in the Era of Globalization* \\ Prepared by Konrad Adler, JaeBin Ahn, Mai Chi Dao \\ Authorized for distribution by Luis Cubeddu
}

December 2018

\begin{abstract}
IMF Working Papers describe research in progress by the author(s) and are published to elicit comments and to encourage debate. The views expressed in IMF Working Papers are those of the author(s) and do not necessarily represent the views of the IMF, its Executive Board, or IMF management.
\end{abstract}

\begin{abstract}
We document a broad-based trend in rising cash holdings of firms across major industrialized countries over the last two decades, a trend that is most pronounced for firms engaged strongly in R\&D activities. Our contributions to the literature are twofold. First, we develop a simple model that brings together the insights from modern trade theory (Melitz, 2003) with those of contract theory in corporate finance (Holmström and Tirole, 1998) to show that increased openness to trade can result in rising returns to innovation and in turn greater demand for cash as firms insure against innovation-induced liquidity risk. Second, we derive sharp empirical predictions and find supporting evidence for them using firm-level data across major $\mathrm{G} 7$ countries during 1995-2014, a period that saw an unprecedented rise in globalization and business innovation.

JEL Classification Numbers: G31, F12, O32
\end{abstract}

Keywords: cash holdings, R\&D, international trade

Authors’ E-Mail Addresses: konrad.adler@tse-fr.eu; jaebin.ahn@snu.ac.kr; mdao@,imf.org

\footnotetext{
* Adler: Toulouse School of Economics. Ahn: Seoul National University. Dao: International Monetary Fund. We thank Giovanni Dell'Ariccia, Carol Corrado, Luis Cubeddu, Aaron Flaaen, Gino Gancia, Kalina Manova, Marti Mestieri, Brent Neiman, and seminar participants at the IMF, Georgetown University, Federal Reserve Bank of Cleveland, the Bank of England, the IMF/WB/WTO Joint Trade Workshop, the Mid-Atlantic Trade Workshop (UVA), Banque de France investment conference and T2M conference (Paris) for helpful comments and discussions.
} 


\section{Introduction}

Since the early 1990s, the beginning of the most recent era of globalisation, firms in many industrial countries have been holding increasingly more liquid assets, mostly in the form of cash. ${ }^{1}$ This trend has coincided with a rise in corporate saving globally, such that the corporate sector as a whole is increasingly becoming a net lender to the rest of the economy (Chen, Karabarbounis and Neiman, 2017), and indeed there is evidence that the increase in corporate saving has been used consistently to accumulate cash (Dao and Maggi, 2018). At the aggregate level, we observe that non-financial corporate saving plays a crucial role for current account dynamics, contributing the lion share to the level and change in current account surpluses, particularly among advanced economies (Dao and Maggi, 2018; IMF, 2017). Understanding drivers of corporate liquidity demand will therefore not only allow us to better understand the financing decision of firms, but also reveal important insights into drivers of current account dynamics.

Notwithstanding the importance of this question and the pervasive, global nature of this trend in corporate behavior, we still know little about how corporate saving and liquidity demand are affected by macroeconomic trends and shocks. One salient feature of modern corporations is their growing global exposure and the associated importance of innovation in product development and business operation. The relationship between trade liberalization and innovation is being debated by a rapidly growing literature. There are several competing hypotheses that predict, and empirical evidence that support either a negative relationship between globalization and innovation activity (Autor, Dorn, Hanson, Pisano and Shu, 2016), potentially due to stronger competition in domestic markets and thus a lower payoff from innovation ('Schumpeterian force'); or a positive one (Bloom, Draca and van Reenen, 2016), possibly due to domestic firms' desire to upgrade their products' quality to gain an edge amid intensifying import competition ('escaping competition'). In a separate literature in corporate finance, the increase in cash holdings has long been documented, and attracted the attention of academic researchers as well as the broader public, even leading to plans for government intervention. ${ }^{2}$. Building on these two strands of lit-

\footnotetext{
${ }^{1}$ Corporate cash holdings has been extensively analyzed for the U.S. by a growing literature; see Bates, Kahle and Stulz (2009), Pinkowitz, Stulz and Williamson (2016), Graham and Leary (2015) to just mention a few. Studies on this topic for non-US corporates are still few: Iskandar-Datta and Jia (2012), Dao and Maggi (2017) are among the few.

${ }^{2}$ For example, Korean government implemented a tax on corporate cash stocks in 2015 (e.g., The Economist, September 27th 2014)
} 
erature, our paper delivers two main contributions. First, we show in a simple model of liquidity management how the increase in liquid asset holdings is linked to increased $R \& D$ spending when trade costs fall. Unlike most previous papers on trade and innovation, our channel operates through expanding export opportunities rather than increasing import competition, and thus offers a way to reconcile the conflicting evidence from Autor et al. (2016) and Bloom et al. (2016). Second, using firm level data from a sample of G7 countries we find evidence suggesting that export opportunities, and only to a much smaller extent import competition, are an important driver behind the increase in R\&D spending and liquid asset holdings.

In our model, the effect of increased trade openness on rising cash holdings operates through the firm's decision to invest in long-term, risky innovation subject to moral hazard. As globalization is associated with expanding export opportunities, the returns to innovation increase as successful innovators are able to capture a larger market. This first part of the mechanism resembles the effect of exports on innovation in Bonfiglioli, Crino and Gancia (2017). Moreover, with investment in innovation being subject to liquidity shocks before the innovation outcome is realized (as in e.g. Aghion, Angeletos, Banerjee and Manova, 2010), the firm must hold enough liquidity to insure against such cost overrun whenever moral hazard prevents it from pledging the full value of the innovation returns to investors. Higher returns to innovation thus induce the firm to hold more cash as they are more likely to innovate, and conditional on being an innovator, to insure against a larger liquidity shock to have more "skin in the game".

We test the main predictions of the model using firm-level data from Thomson Reuters Worldscope, covering mostly large, publicly listed firms in a sample of 5 major advanced economies (the U.S., UK, Japan, France and Germany) during the period 1995-2014. We find that expanding export opportunities and, to a lesser extent, increased import competition, raise cash holdings among incumbent firms. Consistent with the model, the impact on cash holdings is stronger for more productive firms, who are likely to benefit the most from globalization as predicted by the model. Importantly, we also observe that spending on R\&D activities increases as firms experience more export opportunities, with the effect again being stronger for more productive firms. Our baseline empirical strategy considers an instrumental variable approach whereby export and import intensity to and from China are instrumented by other countries' respective average values as in Autor, Dorn and Han- 
son (2013). Alternatively, we measure the reduction in trade cost and associated gains from exporting by using country-industry-specific export tariff rates, computed as a weighted average of trading partners' import tariffs, which strongly confirms the robustness of main results.

On the theoretical front, this paper combines insights from both modern trade theory (Melitz, 2003), which emphasizes firm heterogeneity in intra-industry trade, as well as liquidity management models of corporate finance (Holmström and Tirole, 1998), which rely on the theory of optimal contract to derive the demand for liquidity as an outcome of risky project financing under moral hazard. The innovation of our paper is to combine these two strands of theoretical literatures and show that globalization, apart from changing the firm-level and industry-wide productivity, can also lead to systematic shifts in corporate balance sheet composition and demand for liquid assets. At the same time, our model offers insights that are consistent with the previous literature on the role of finance in exporter selection (e.g., Chaney, 2016; Manova, 2013), suggesting that varying capacity in obtaining liquidity, be it through access to external borrowing, equity issuance or internal cash flow, can play an important role in firms' selection into exporting, particularly in innovation-intensive industries.

On the empirical trade front, our paper is related to Bustos (2011) and Lileeva and Trefler (2010) who study the impact of trade liberalizations on productivity and innovation at the plant level and find that export opportunities matter for innovation. Most recently, Autor et al. (2016) analyze the impact of Chinese import competition on innovation by US firms, while Bloom et al. (2016) study the impact of Chinese import competition on measures of innovation of affected European firms. We differ from these studies in two ways: First, we disentangle the impact of globalization into the channel of export opportunities from that of import competition, showing that they differ in important ways. While most papers on trade and innovation have focused on the import competition channel, Aghion, Bergeaud, Lequien and Melitz (2018) and Coelli, Moxnes and Ulltveit-Moe (2017) are among the few studies that have also empirically analyzed the export market channel. Second, to the best of our knowledge, ours is the first paper to link the trend in globalization-induced innovation to shifts in corporate liquidity demand.

Given the connection to corporate liquidity, our paper also builds on a large volume of work in empirical corporate finance that examines patterns and determinants of cash hold- 
ings, primarily of public firms in the U.S. (e.g. Bates et al. 2009, Pinkowitz et al. 2016). In Lyandres and Palazzo (2016), cash holdings and innovation are linked through a strategic motive. Cash serves as a commitment device for innovation and in equilibrium, depend on the product market structure and financial constraints that a firm faces. Similar to our paper, Falato, Kadyrzhanova and Sim (2013) also attribute the rise in cash holdings in the U.S. to the increasing importance of intangible assets (measuring the stock of innovation). However, apart from the narrower sample (US Compustat firms), they do not examine the role of globalization in driving the intensity of innovation, a key source for intangible capital accumulation in our model, and instead, relate the need for cash holdings to the low collateralizability of intangible assets. In our model, the motive for cash holdings arises from the nature of investment in innovation, that is, its exposure to cost overrun and moral hazard. ${ }^{3}$

The rest of the paper is organized as follows: section 2 presents some key stylized facts regarding cash holdings, innovation intensity and globalization. Section 3 introduces a model linking the expansion of export opportunities with the firm's decision to invest in innovation and the implications for cash holdings. Section 4 then outlines the empirical strategy and tests key predictions of the model. Section 5 concludes.

\section{Stylized facts}

The increase in corporate cash holdings is well documented for US corporations, but is in fact a more widespread phenomenon. Figure 1 plots the mean and median cash ratio of all firms in each of the five countries in our sample and shows that listed firms in all countries have been holding more and more cash relative to the size of their overall assets at least since the mid 1990's. Interestingly, while the share of cash in total assets has broadly flattened in the U.S. in the mid 2000's, the upward trend continues unabated in the other G7 countries, and only started to pick up in Japan after the global financial crisis. A related macro literature has also documented the concurrent rise in corporate saving in major advanced and emerging economies (e.g. Chen et al. 2017, Dao and Maggi, 2018), suggesting that the rise in cash stock has been financed in part by increased retained earnings, in

\footnotetext{
${ }^{3}$ Other motives for cash holdings and corporate saving, less related to our paper's channel, have also found support in the literature: e.g. Foley, Hatzell, Titman and Twite (2007) and Armenter and Hnatkovska (2017) for tax motive, Azar, Kagy and Schmalz (2016) for cost of carry, and Dittmar, Mahrt-Smith and Servaes (2003) for corporate governance motives.
} 
addition to debt and equity issuance.

At the same time, it is well known that firms have been investing increasingly in intangible assets, instead of physical fixed assets, reflecting the rising importance of knowledge, organizational and other intangible capital as inputs in production (see e.g. Corrado and Hulten, 2010; Alexander and Eberly, 2016). According to some estimates, the stock of intangible has approached that of tangible capital in the U.S. corporate sector during the past decade (Falato et al., 2013). While less is known for other countries other than the U.S., a first look at the data on the share of intangible in overall assets in some of the other G7 countries also reveals a strongly increasing trend (Figure 2).

Moreover, the two trends are not unrelated, as becomes evident in the evolution of their cross-sectional distribution. Figure 3, which plots the evolution of the median cash ratio for firms in each tercile of innovation intensity in each country, shows that firms with high R\&D intensity (measured as R\&D spending as a share of total sales) have on average higher cash ratios in all five countries. Also, in country year episodes where the increase in cash ratio has been most pronounced, as e.g. in the U.S. and Germany in the early 2000's, the increase is steepest for the most innovation-intensive firms. The higher level and steeper trend in cash holdings for innovating firms suggest that the decision to innovate and that over the optimal level of cash holdings are closely related. Firms with higher cash ratios also tend to spend more not only on $R \& D$, but also on other activities classified as overhead costs, or Selling, General and Administration (SG\&A), comprising advertisement, marketing, training etc. which are not directly linked to current production. Figure 4 plots the ratio of SG\& A spending (in percent of sales) for different terciles of cash ratios across firms and documents that cash-rich firms tend to spend relatively more on such overhead outlays which are typically aimed at maintaining or boosting long-term profitability.

At the same time as innovation and corporate liquidity demand surged, the world economy experienced what some have dubbed "hyper-globalization" (Subramanian and Kessler, 2013), a period of unprecedented acceleration in cross-border trade, driven primarily by the integration of China and other emerging markets into the world trading system. The pattern is not a mere co-incidence of unrelated time trends, but is corroborated by cross-sectional correlation. When plotting advanced economies' evolution of aggregate cash ratios during 1995-2015 and of their export shares during the same period, 
we observe a strong positive correlation (Figure 5). 4 A one standard deviation increase in the export to GDP ratio is associated with roughly one standard deviation increase in the cash to asset ratio in a given country over time. The prima-facie evidence in Figures 3 and 5 hence jointly suggest a potentially important relationship between globalization, innovation and cash holdings.

There is evidence that the changing composition of firms in the U.S. has increased the average cash ratio, as younger cohorts of firms launching IPO have been entering the sample with higher cash holdings than incumbent ones in the 1980's to late 1990's (Begenau and Palazzo, 2016). However, this composition effect does not appear to be dominant in the later years and across a broader sample of other industrial countries. Figure 6 shows the evolution of median cash ratio by cohorts entering the sample in non-overlapping 5year periods. While subsequent cohorts entering the sample have been contributing positively to the average cash ratio up until the late 1990's (the 1996-2000 cohorts lying above the previous cohort line in most countries), this relationship fails to hold broadly for subsequent cohorts, with the exception of Japan, where entering cohorts continue to be more cash-rich than incumbent firms. Even in the case of Japan though, the increase in average cash ratio after 2010 is driven also strongly by within-cohort trends. In all other countries, any upward trend in cash-holding post 2000 is predominantly driven by within-cohort trends, suggesting that the composition effect only played a limited role and within-firm dynamics to be of primary importance, particularly in the last decade.

Finally, we also take a more granular look at entering/exiting versus incumbent firms in each year (not only 5-year cohorts) by decomposing the aggregate change in cash to asset ratio into intensive and extensive margins, following Begenau and Palazzo (2016).

\footnotetext{
${ }^{4}$ Of course export and import shares are highly correlated at the country level, so the positive correlation could be also driven by enhanced import competition. However, when controlling for both export and import shares, we see only a weak and statistically insignificant positive correlation between cash ratio and import shares, while the coefficient on export shares remain significant and of similar magnitude as in the bivariate regression.
} 


$$
\begin{aligned}
\Delta \frac{C H_{t}}{A_{t}} & =\underbrace{\left(\frac{A_{t}^{I}}{A_{t}^{I}+A_{t}^{\text {entr }}} \frac{C H_{t}^{I}}{A_{t}^{I}}-\frac{A_{t-1}^{I}}{A_{t-1}^{I}+A_{t-1}^{\text {exit }}} \frac{C H_{t-1}^{I}}{A_{t-1}^{I}}\right)}_{\text {intensive margin }} \\
+ & \underbrace{\left(\frac{A_{t}^{\text {entr }}}{A_{t}^{I}+A_{t}^{\text {entr }}} \frac{C H_{t}^{\text {entr }}}{A_{t}^{\text {entr }}}-\frac{A_{t-1}^{I}}{A_{t-1}^{I}+A_{t-1}^{\text {exit }}} \frac{C H_{t-1}^{\text {exit }}}{A_{t-1}^{\text {exit }}}\right)}_{\text {extensive margin }}
\end{aligned}
$$

with the superscript $I$ designating the corresponding variable (cash stock $C H$ and total assets $A$ ) of incumbent firms. Figure 7 shows the cumulative contribution of the extensive and intensive margin to the total change in aggregate cash ratios. In all countries except for Japan, the intensive margin has been contributing positively to the average cash ratio, whereas the composition of firms has been exerting a negative effect on the aggregate cash ratio, consistent with the cohort-based calculations. In Japan, during the period associated with an increasing overall cash ratio starting from 2010, it has also been the intensive margin, that is, the cash evolution among incumbent firms, that has driven the overall increase.

The relevance of the intensive margin for the rising trend in cash holdings is consistent with the role of within-firm increase in net saving rates (retained earnings) documented in Chen et al. (2017) and Dao and Maggi (2018).

\section{A model of liquidity demand and export-oriented innovation}

Motivated by the preceding stylized facts, in the following, we present the main elements of a model that links the decision on cash holding within a firm to its exposure to trade openness. This model generates an insurance mechanism even in the presence of riskneutral agents. The demand for liquidity arises from the need to fund cost overruns resulting from long-term investment (such as innovation or other investment in intangible capital) which in turn are spurred by increased globalization. Rising globalization expands export opportunities for the most productive firms and thus boosts returns to being in the top tail of the distribution. This export or market access aspect of globalization, less studied than the import exposure in the literature, thus increases incentives for domestic firms 
to innovate and move up in the productivity distribution. ${ }^{5}$ By doing so, the optimal contract with investors also requires them to hold more cash in order to fund cost overruns and other liquidity shocks occurring before the innovation bears fruit.

\subsection{Model set-up}

The framework is a 3-period model combining motive for cash holdings as in Holmström and Tirole (1998) and exporter selection with heterogenous firms as in Melitz (2003). In particular, in period $\mathbf{t}=\mathbf{0}$, an incumbent domestic firm has a given level of productivity $\phi_{0}$ and realizes per period profit $\pi\left(\phi_{0}\right)$, where $\pi$ is a non-decreasing continuous function in firm productivity which we will further specify below. The firm decides whether to invest in innovation to upgrade its productivity to a higher level $\phi \geq \phi_{0}$ at fixed cost $I$. Importantly, we abstract from firm entry and exit in the domestic market.

In the intermediate stage $\mathbf{t}=\mathbf{1}$, if the firm has invested in innovation, it is exposed to a stochastic liquidity shock in the magnitude $\rho$ which is distributed according to the cdf $F(\rho)$ on the support $[0, \infty)$. This liquidity shock can be seen as a cost over-run or a stochastic reinvestment need. If the firm does not pay $\rho$, its investment is lost and it reverts to its status quo. If it pays $\rho$, it survives until the next period. We assume that when the liquidity shock hits, the firm cannot rely on borrowing or raising capital sufficiently fast to entirely cover the cost overrun. Therefore, the funds to cover the liquidity shock need to be hoarded as cash in advance. ${ }^{6}$

Upon surviving the liquidity shock, the firm reaps the benefit of its innovation investment in period $\mathbf{t}=\mathbf{2}$ by drawing a new productivity from a Pareto distribution with density function $g(\phi)$ over the support $\left[\phi_{0}, \infty\right)$, and shape parameter $\kappa$ which pins down the dispersion of the distribution. A lower $\kappa$ represents a thicker upper-tail distribution and hence a higher probability of drawing a high productivity.

After drawing the new productivity, the firm has an opportunity to become an exporter. Exporting requires paying fixed costs $f_{X}$ and variable (iceberg) costs $\tau>1$ as in Melitz

\footnotetext{
${ }^{5}$ A similar mechanism by which exports boosts innovation is presented in Bonfiglioli et al. (2017).

${ }^{6}$ Later, in the Appendix, we relax this simplifying assumption and endogenize the firm's financing decision as a solution of the optimal contract in the presence of information asymmetry between the firm and outside investors that gives rise to moral hazard. In short, firms will always choose to hold cash in advance to insure against liquidity shocks. This is because moral hazard will prevent the firm from being able to commit the full net present value of the innovation to investors in certain instances, under which the firm would then forego positive investment opportunities were it to rely only on borrowing at the time of the liquidity shock.
} 
(2003). Therefore, if the firm's productivity draw is above a cutoff value, it will serve both the domestic and foreign markets, whereas if it is below the cutoff, it continues to serve the domestic market only, but still operates at higher productivity $\phi \geq \phi_{0}$ and realizes higher profit relative to not innovating.

The timing of the events are illustrated in Figure 8.

\subsection{Model solution}

We solve the model backwards by first considering the exporter selection stage $t=2$. As in Melitz (2003), we assume consumers in both the domestic and export markets have the same CES utility over a continuum of substitutable goods with elasticity of substitution $\sigma>1$, and producers (firms) being monopolistically competitive. Conditional on drawing productivity $\phi$, the firm's profit as a function of its new productivity is given by its profit in domestic and export markets (see derivation in Appendix):

$$
\pi(\phi)=\pi^{D}(\phi)+\pi^{X}(\phi)=M \phi^{\sigma-1}+M^{X}\left(\frac{\phi}{\tau}\right)^{\sigma-1}-f_{X}
$$

with $M, M^{X}$ being composite terms reflecting total demand in domestic and export markets, taken as given by the firm, and $f_{X}$ and $\tau$ being the fixed and variable cost of exporting as introduced above. Since profits are increasing in $\phi$, the firm will only export if its productivity draw is above a cutoff $\phi_{X}^{*}$ which is pinned down by the zero profit condition for exporting:

$$
\phi_{X}^{*}=\tau\left(\frac{f_{x}}{M^{X}}\right)^{\frac{1}{\sigma-1}}
$$

Intuitively, the exporting cutoff is lower with lower trade costs and larger export markets. The ex-ante expected profit is therefore:

$$
E(\pi)=\int_{\phi_{0}}^{\infty} M \phi^{\sigma-1} g(\phi) d \phi+\int_{\phi_{X}^{*}}^{\infty}\left[M^{X}\left(\frac{\phi}{\tau}\right)^{\sigma-1}-f_{X}\right] g(\phi) d \phi
$$

where $g(\phi)$ is the density function of the new (post-innovation) productivity distribution with shape parameter $\kappa$. Applying the properties and parameters of the Pareto distribution, defining $\xi=\sigma-1$, we can solve for expected profit conditional on innovating to 
be:

$$
E(\pi)=\frac{M \kappa}{\kappa-\xi} \phi_{0}^{\xi}+\frac{\kappa f_{x}}{\kappa-\xi} \phi_{X}^{*}\left(f_{x}, \tau, M^{x}\right)^{-\kappa} \phi_{0}^{\kappa}
$$

and the return from innovation is therefore:

$$
E\left(R\left(\phi_{0}\right)\right)=E(\pi)-\pi_{0}=\frac{M \xi}{\kappa-\xi} \phi_{0}^{\xi}+\frac{\kappa f_{x}}{\kappa-\xi} \phi_{X}^{*}\left(f_{x}, \tau, M^{x}\right)^{-\kappa} \phi_{0}^{\kappa},
$$

where we have $\frac{\partial E(\pi)}{\partial \tau}<0$ and $\frac{\partial E(\pi)}{\partial M^{x}}>0$. With lower trade costs and/or larger export markets, the profit for each exporter with given productivity is higher, at the same time as the probability of becoming an exporter is higher, both contributing to higher ex-ante expected profits. At the same time, higher initial productivity $\phi_{0}$ raises expected profit conditional on innovating, as higher $\phi_{0}$, being the lower bound for the new productivity draw, leads on average to a higher level of post-innovation productivity and hence results in higher expected profit in domestic as well as export markets.

Now moving to $t=1$, conditional on being hit by a liquidity shock $\rho$, it immediately follows that the firm should continue whenever $\rho$ is not too high so as to maintain a positive net payoff from the innovation. Denoting this threshold by $\rho^{1}$, we can derive its value from the first order condition of:

$$
\max _{\rho^{1}} N P V=\max _{\rho^{1}} \int_{0}^{\rho^{1}}[E(R(\phi))-\rho] f(\rho) d \rho-I,
$$

which yields $\rho^{1}=E\left(R\left(\phi_{0}\right)\right)$, that is, the firm maximizes the net present value (NPV) of the innovation project by covering the liquidity shock/cost overrun as long as it does not exceed the expected profit from continuing the innovation. This first-best threshold $\rho^{1}$ then is the cash amount the firm needs to hold in $t=0$.

In $t=0$, if the net present value of the innovation project is positive (which, for given $I$, effectively requires a minimum productivity level for innovating firms), the firm will want to innovate and pay the upfront amount $I$ plus hold the cash amount $\rho^{1}$ to insure against the liquidity shock in $t=1$.

We establish the following main results.

Result 1 Only firms above a minimum productivity cutoff will innovate. Innovating firms hold more cash than non-innovating firms. Innovating firms with higher initial productivity hold more cash. 
From equation (6) above, we can express the maximized NPV for a firm with given initial productivity $\phi_{0}$ as

$$
\operatorname{MNPV}\left(\phi_{0}\right)=\int_{0}^{\rho^{1}\left(\phi_{0}\right)}\left[E\left(R\left(\phi_{0}\right)\right)-\rho\right] f(\rho) d \rho-I,
$$

Only firms with positive expected MNPV from innovating will do so. In other words, only firms with initial productivity above the cutoff level $\phi_{0}^{1}$ will choose to innovate, where the cutoff level is obtained from the break-even condition $\operatorname{MNPV}\left(\phi_{0}^{1}\right)=0$. These firms will pay the upfront cost $I$ and hoard the cash amount $\rho^{1}$ to cover subsequent liquidity risk. All else equal, therefore, their cash holdings will be higher by the amount $\rho^{1}$ compared to non-innovating firms. Moreover, from equation (5), we know:

$$
\frac{\partial \rho^{1}\left(\phi_{0}\right)}{\partial \phi_{0}}=\frac{\partial E\left(R\left(\phi_{0}\right)\right)}{\partial \phi_{0}}=\frac{M \xi^{2}}{\kappa-\xi} \phi_{0}^{\xi-1}+\frac{\kappa^{2} f_{x}}{\kappa-\xi} \phi_{X}^{*}\left(f_{x}, \tau\right)^{-\kappa} \phi_{0}^{\kappa-1}>0,
$$

so that the innovation-accompanying amount of cash holdings increases with the ex-ante productivity of the firm. This crucial result distinguishes our motive of cash holdings from others in the literature where demand for cash is a result of intangible capital shrinking the firm's collateral base and external financing capacity (see e.g. Falato et al. 2013). Unlike the collateral channel that generates a stronger motive of cash holdings for smaller firms facing more financial frictions, the innovation channel in our model, encompassing investment in intangible capital, leads to a higher level of cash holdings for larger, more productive firms. This is because more productive firms expect more payoff from productivity enhancing innovation and hence are willing to absorb larger liquidity shocks in the interim to keep their "skin in the game".

Result 2 Conditional on being an innovating firm, globalization in terms of lower trade costs $\tau$ and/or expanded foreign market size $M^{X}$ increases the level of the firm's cash holdings, that is $\frac{\partial \rho^{1}}{\partial \tau}<0, \frac{\partial \rho^{1}}{\partial M^{X}}>0$. Moreover, more productive firms increase their cash holdings more in response to the same shock than less productive ones.

This result follows from taking the derivative of $\rho^{1}$ with respect to $M^{X}$, that is:

$$
\frac{\partial \rho^{1}}{\partial M^{X}}=\frac{\partial E(R)}{\partial M^{X}}=\Omega\left(\tau, M^{X}, f_{X}, \kappa, \sigma\right) \phi_{0}^{\kappa}>0,
$$

where $\Omega()>$.0 is a composite function of underlying parameters of the model taking on 
positive values (and similarly for a reduction in $\tau$ ). A positive export shock increases the returns from innovation and hence makes firms willing to absorb larger liquidity shocks, therefore raising the optimal cash holdings of any firm above the innovation productivity cutoff. In addition, as $\kappa>0$, it follows that this increase in cash holdings from a positive export shock is increasing in the underlying productivity level $\phi_{0}$. Intuitively, a more productive firm is more able to translate the better export opportunity into higher profits, and thus will hold more cash to withstand larger liquidity shocks so as to reap these profits eventually.

Result 3 Globalization in terms of lower trade costs $\tau$ and/or expanded foreign market size $M^{X}$ reduces the productivity cutoff for innovation and thus, for a given distribution of initial productivity across firms, increases innovation activity and the average cash holdings among incumbent firms in the industry.

As derived in result 1, the minimum productivity cutoff for innovating firms is given by the break-even condition $M N P V\left(\phi_{0}^{1}\right)=0$. At the same time, we know that a positive export shock raises the $M N P V$ for all values of $\phi_{0}$, as per envelope theorem, we have $\frac{\partial M N P V}{\partial M^{X}}=F\left(\rho^{1}\right) \frac{\partial E(R)}{\partial M^{X}}>0$. It immediately follows that for given innovation costs $I$, a positive globalization shock lowers the minimum productivity cutoff for firms to innovate. In other words, a larger $M_{X}$ and/or lower $\tau$ shift down the inverse function $M N P V^{-1}($. and reduce $\phi_{0}^{1}=M N P V^{-1}(0)$ to the lower value $\phi_{0}^{2}$.

All three results regarding the schedule of optimal cash holdings as a function of the initial productivity, the set of innovating firms, and the shifted curve triggered by more trade openness (through lower trade costs and/or larger markets) are depicted in Figure 9. As derived above, the schedule of optimal cash holdings is a convex positive function of the underlying productivity level above the minimum productivity cutoff $\phi_{0}^{1}$. A trade liberalization that lowers trade cost $\tau$ or expands access to foreign markets $M_{X}$ shifts the schedule inward and for any given level of $\phi_{0}$, steepens the slope of the cash holdings schedule. As a result, the increase in cash holdings is disproportionately larger for more productive firms, and zero for firms below the cutoff. Moreover, for any given productivity distribution, export liberalization also expands the set of innovating firms by reducing the cutoff. ${ }^{7}$

\footnotetext{
${ }^{7}$ In the Appendix, we relax the financing constraint in $t=1$ and allow the firm to borrow / raise equity at the time of the liquidity shock, but subject to well-known informational asymmetry that gives rise to moral
} 


\subsection{Testable implications}

The main testable predictions of the model can be summarized as the following:

- For the within-firm variation in cash holdings, Result 1 and Result 2 predict that a firm's cash holdings should increase with export opportunities only if the firm has high enough underlying productivity. Using different proxies for a firm's productivity, we should see that the marginal impact of trade openness on cash holdings is stronger for more productive firms. Moreover, the differential of this marginal impact should be most pronounced when comparing firms with the highest and lowest productivity levels, while comparison with firms of intermediate productivity is less unambiguous in the extended version of the model (see Figure A.3). Importantly, this differential prediction that export opportunities affect firms with higher productivity more also allows us to discriminate between our channel and those relying on innovation interacting with financial constraints such as Falato et al. (2013), where innovation raises cash holdings more in smaller/less productive firms, as they face more external financing constraint. ${ }^{8}$

- Result 2 predicts that, if the firm has high enough productivity, the increase in cash holdings facilitates more innovation activity by making firms more able to absorb liq-

uidity shocks in the interim. Measured spending on innovation (equal $I+\int_{0}^{\rho^{1}} \rho f(\rho) d \rho$ in the model) will therefore also increase with expanding export opportunities. ${ }^{9}$ Similar to the result for cash, this positive effect should be stronger for larger (or more productive/more profitable/export-oriented) firms.

- At the industry-level within a country, Result 3 implies that cash holdings increases on average in an industry when its export opportunities increase. In line with the model, we should also see the average industry-wide R\&D spending, a measure of innovation intensity at the industry-level, increase at the same time. However, the average industry-level outcome may be small and hard to be identified due to the

hazard. We show that all 3 main results still go through, in particular, firms still choose to hold the cash in advance as they cannot commit to the full NPV of the innovation project due to moral hazard.

${ }^{8}$ In other words, in our model, the less productive/typically smaller a firm is, the lower are its expected returns from innovation and the less cash it will be willing to hold. In contrast, in alternative models, the more constrained a firm is by lack of external financing capacity, the more cash it must hold to self-insure against productivity shocks.

${ }^{9}$ Note that this prediction applies to spending on innovation, not necessarily its outcome or quality. 
heterogeneity in the impact of globalization across firms with varying level of productivity. Moreover, the industry result relies on the prediction that improved market access also allows new firms to become innovators (as the asset threshold falls). However, this extensive margin of innovation is not possible to measure in the R\&D data, as missing entries for R\&D spending can reflect either a non-reporting of actual spending or zero spending on R\&D. ${ }^{10}$ We therefore focus on the intensive margin of innovation and associated cash holdings (Results 1 and 2) in the empirical analysis below.

\section{Empirical Analysis}

\subsection{Data}

We use Thomson Reuter Worldscope data spanning the period 1995-2014 for five major industrial countries where coverage of publicly listed firms is among the most comprehensive: the U.S., UK, Germany, Japan, and France. Following the literature, excluded are firms with: negative equity, negative sales and missing value for total assets, as well as firms in the utilities and financial sector (sic 6000-6799, sic 4900-4999, sic 9000-9999, sic 1800-1999).

Table 1 summarizes the median of some key variables for each country in the sample. Overall, firms hold about 10 percent of total assets in cash and short-term investment (cashlike instruments), with Japanese firms having the highest cash ratio of 15 percent for the median firm and being on average the largest in terms of asset size. Among firms that have positive R\&D spending, US firms are the most active in terms of investing in innovation, spending on average over twice as much on R\&D as a share of their revenues than firms in other countries, while they are also the least likely to pay out dividends. ${ }^{11}$

Although the dataset contains consolidated accounts of mostly publicly listed firms, evidence in Dao and Maggi (2018) confirms that the combined cash holdings and net lending rates of these large firms, when added up, track well the aggregate evolution of corresponding variables from official flow of funds and sectoral national accounts data. This

\footnotetext{
${ }^{10}$ This is a well-known limitation of firm-level R\&D obtained from balance sheet and financial statements data, see e.g. Lev and Radhakrishnan (2005).

${ }^{11}$ While we have almost 200,000 firm-year observations over which these summary statistics are computed, in the following, the sample is greatly reduced when we seek to compute a firm-level or sector-level measure of exposure to export and import.
} 
finding on aggregate representativeness is consistent with other studies focusing exclusively on the U.S. corporate sector, which also established that the corporate net lending as well as cash holdings is extremely concentrated among large firms (see Armenter, 2012 and references therein). Understanding drivers of cash holdings and saving by listed firms can therefore shed light on forces that drive the evolution of overall private saving (to which the corporate sector contributes substantially), real interest rates and the current account.

Worldscope provides two main four-digit-level standard industry classifications (SIC) for each firm, accompanied by the amount of sales of each category. Using an initial year's product segment sales shares, we can construct each firm's exposure to export opportunities and import competition by combining this firm-level data with industry-level trade and tariff data. The bilateral trade data, sector output data, and MFN tariff data come from the UN Comtrade database, World Input Output Database (WIOD), and TRAINS database, respectively, all of which are then matched to the SIC code of each firm in an initial year to derive sector- or firm-specific weighted average exposure to export and import shocks (more details below).

Figure 10 illustrates a rapidly growing role of China in trade with advanced economies in our sample. It also highlights substantial variation across countries and industries, providing a source of identification for our econometric analysis below. Similarly, Figure 11 describes the extent of tariff liberalization in our sample economies and their trading partners. It is worth noting that import tariff liberalization has been stagnant over the last two decades in our sample countries, mainly because their tariff rates had already reached low levels by the mid 1990's. In contrast, their trading partners, many of them emerging market economies, whose tariff rates were relatively high, have undergone substantial tariff liberalization over the same period. In this regard, as far as tariff rates are concerned, firms in our sample appear to have experienced not so much import shocks as positive export shocks. This fact underscores the importance to look at both the export and import margins when analyzing the effect of trade.

Our empirical strategy essentially relies on a difference-in-difference identification of the heterogeneous effect of export shocks across firms with differential initial productivity level $\phi_{0}$. In a multi-factor production environment, the variable $\phi_{0}$ should correspond to firm-level total factor productivity (TFP). Crucial elements for computing firm-level TFP are however not available in our dataset (such as intermediate inputs, prices etc). Thus, we 
will have to rely on simple proxies following the literature such as size, labor productivity, export intensity, or profitability. ${ }^{12}$

Another important aspect of our model is the firm's decision to engage in long-term investment in innovation. We understand innovation here as any activity that requires long-term financial commitment with uncertain outcomes, and exposes the firm to liquidity risk in the interim. $\mathrm{R} \& \mathrm{D}$ is one category of such innovation activities, and evidence exists that firms indeed use cash holdings to smooth R\&D expenditure, which is costly to adjust, in response to financing shocks (Brown and Petersen, 2011). But similar risk applies to other activity of the firm that increases its intangible capital stock, in particular investment in its human, organizational and social capital (see Lev and Radhakrishnan, 2005; Eisfeldt and Papanikolaou, 2013). The reason is because spending on such activities as internal training, brand development, development of distribution networks etc. require steady and long-term outlays, increasing the share of quasi-fixed costs and decoupling the firm's revenues from its operating expenditure, hence increasing its exposure to liquidity shortage (see Srivastava and Tse, 2016). However, we do not have data on such activities by firms. The closest measure encompassing such intangible capital enhancing spending are spending on so-called SG\&A (selling, general and administration costs), which however also contain non-intangible enhancing expenses such as social security taxes, pension costs, and other overhead costs. We therefore consider both R\&D and SG\&A spending as our measure of innovation activity when investigating the underlying channel through which globalization leads to an increase in cash holdings.

\subsection{Empirical Strategy}

The main testable hypothesis from the model in this paper is that rising globalization, particularly in terms of expanded export opportunities, would lead to an increase in cash holdings, and particularly more so for innovating firm with higher productivity. Moreover, the model suggests that it occurs through boosting incentive for innovation, resulting in an increase in innovation spending, more so in firms with higher initial productivity.

\footnotetext{
${ }^{12}$ Modern heterogeneous-firms trade models center on the productivity sorting of exporter status: that is, the most productive firms become exporters, as has been strongly supported in the empirical trade literature. Moreover, it has been well established that larger firms are more likely to be exporters (Bernard, Jensen, Redding, and Schott, 2007; Bernard, Jensen, and Schott, 2009). Given the likely noisiness in TFP estimates, researchers have also relied on various proxies for the productivity level, ranging from size, labor productivity, export intensity, to profitability (e.g., Verhoogen, 2008).
} 
Accordingly, at the firm-level, we use the following baseline specification to test the main hypotheses:

$$
Y_{i j c t}=\beta^{e x p} S H O C K_{j c t}^{e x p}+\beta^{i m p} S H O C K_{j c t}^{i m p}+\Theta Z_{i j c t}+F E+\varepsilon_{i j c t},
$$

where $Y_{i j c t}$ is the dependent variable of interest, primarily the ratio of cash holdings to total assets in $\log$ for firm $i$ in two-digit-level sector $j$ and country $c$ at year $t . S H O C K_{j c t}^{\text {exp }}$ captures the country-sector-year-level potential export opportunities that could stem from, for instance, improved foreign market access or increased demand abroad. Likewise, $S H O C K_{j c t}^{i m p}$ denotes the degree of country-sector-year-level import competition that domestic firms face. As such, export and import shocks are separately estimated. $Z_{i j c t}$ is a set of other relevant control variables such as a firm's total sales volume, operating cash flow, etc. The baseline regression includes firm fixed effects to explore within-firm variation over time in response to changing degrees of globalization. In addition, country-year fixed effects would absorb any other macroeconomic factors that could affect a firm's cash holding decision.

As spelled out above, the model predicts that the effect of globalization should be more pronounced for firms with higher initial productivity, as they are more likely to undertake innovation-related investment (due to selection into innovation) and more able to translate the better export opportunity into higher profits (due to the post-innovation productivity distribution). This prediction can be tested by including additional interaction terms to capture heterogeneous responses along different levels of productivity proxied by, for instance, size (measured by total assets), productivity (measured by labor productivity), export intensity (measured by the share of foreign sales), or profitability (measured by net income per employee). Specifically, we assign each firm a tercile dummy variable encoding its relative position in the distribution of the respective productivity proxy in a given country and year. The corresponding specification can then be expressed as:

$Y_{i j c t}=\sum_{k=e x p, i m p}\left[\beta^{k} S H O C K_{j c t}^{k}+\sum_{l=2,3} \beta_{l}^{k} S H O C K_{j c t}^{k} * I_{i j c t, l}\right]+\Theta Z_{i j c t}+F E+\varepsilon_{i j c t}$, where $I_{i j c t, l}$ is a tercile dummy variable, whose stand-alone level is also included in $Z_{i j c t}$. A typical empirical challenge in identifying the causal effect of globalization on firmlevel decisions is likely to prevail in this setting, not least because our sample is composed 
of publicly listed firms, some of which are large enough to influence potential globalization measures. In an effort to alleviate such endogeneity concerns, among several possible candidate variables for $S H O C K_{j c t}^{e x p, i m p}$, we employ measures of exports to, and imports from, China-both scaled by the two-digit country-sector-level output-as a measure for export opportunities and import competition, respectively:

$$
S H O C K_{j c t}^{e x p}=\left(\frac{\text { Total Exports to China }}{\text { Total Output }}\right)_{j c t}
$$

and

$$
S H O C K_{j c t}^{i m p}=\left(\frac{\text { Total Imports from China }}{\text { Total Output }}\right)_{j c t} .
$$

To the extent that much of the recent rise in trade with China is driven by supply-side and demand-side shocks from China-productivity shocks for China's exports and unilateral trade liberalization for China's imports-, these measures are expected to embody exogenous shocks from the perspective of a firm in any given G7 partner country. Still, however, we acknowledge that such measures are not entirely immune to potential endogeneity biases. We thus follow Autor et al. (2013) and Autor et al. (2016) to further instrument them with the corresponding average values of other advanced economies. This instrumental variable approach allows us to extract China-made exogenous shocks in each industry, which in turn underlie the rising role of China in global trade. ${ }^{13}$ Such Chinaspecific shocks common to all third partner countries should therefore be strongly correlated with the change in export opportunities and import competition in a given partner country, but would not be directly related to a firm's cash holdings and innovation spending once their overall performance and other macroeconomic specific shocks are controlled for.

Past evidence, as discussed in detail in Autor et al. (2013), tends to lend support for the validity of our identification strategy in that demand and/or technology shocks common to major advanced economies played only a minor role in explaining the recent surge in China's trade. Nevertheless, caution is warranted in interpreting the estimated coefficients below, in case our instrumental variables are still contaminated by any remaining

\footnotetext{
${ }^{13}$ In essence, our import shock measure and its instrumental variable exactly follow Autor et al. (2013) and Autor et al. (2016). We apply their idea similarly to construct export shock measures and instrumental variables as in Ahn and Duval (2018), which is in turn comparable to the export demand shock measure developed in Mayer, Melitz, and Ottaviano (2016).
} 
correlated demand and supply shocks across countries, such as sector-year-level common trend in technological growth. ${ }^{14}$ As robustness checks, we thus also consider alternative firm-level trade shock measures, thereby ensuring sufficient variation across firms even with additional sector-year fixed effects to absorb any such concerns. ${ }^{15}$

The first alternative measure is constructed as the weighted average of four-digit countrysector-level shocks:

$$
S H O C K_{i j c t}^{e x p}=\sum_{j^{\prime}} \omega_{i j^{\prime} c}\left(\frac{\text { Total Exports to China }}{\text { Total Exports }}\right)_{j^{\prime} c t},
$$

for exports, and

$$
S H O C K_{i j c t}^{i m p}=\sum_{j^{\prime}} \omega_{i j^{\prime} c}\left(\frac{\text { Total Imports from China }}{\text { Total Imports }}\right)_{j^{\prime} c t},
$$

for imports, respectively, where the share of exports to (imports from) China in total exports (imports) is used as a four-digit country-sector-level export (import) shock measure and the weights are calculated using the initial year's sales share of the primary and secondary four-digit SIC codes, $j^{\prime}$, for each firm. That is, the country-sector level export/import exposure to China is converted to a firm-level one using weights $\omega_{i j^{\prime} c}$, which corresponds to the respective share of a given firm's sales in each four-digit sector in the initial year. As above, we further consider instrumental variables for 2SLS estimation by taking the corresponding average values from other advanced economies while keeping the firm-level weight.

The second alternative measure is constructed by replacing China-based trade shock measures with tariff-based measures:

$$
M F N_{i j c t}^{k}=\sum_{j^{\prime}} \omega_{i j^{\prime} c}\left(\tau^{k}\right)_{j^{\prime} c t-1}
$$

for $k=\{\exp , i m p\}$, where the weight $\omega_{i j^{\prime} c}$ is defined as above, while $\tau_{c j^{\prime}}^{i m p}$ denotes country $c^{\prime} s$ most favored nation (MFN) tariff rate imposed on imported goods from industry $j^{\prime}$,

\footnotetext{
${ }^{14}$ In principle, we could include sector-year fixed effects in the baseline specification. However, our instrumental variable approach aims to extract sector-year-level common exogenous trade shocks induced by China, which would leave little variation across countries once sector-year fixed effects are included.

${ }^{15}$ The baseline measure is defined at two-digit country-sector level because total output data from World Input Output Database (WIOD) is available at two-digit sector level. Since most firms in our sample report two distinct primary and secondary four-digit sectors that belong to a single two-digit sector, it is not feasible to construct firm-level trade shock variables using two-digit country-sector-level measures.
} 
and $\tau_{c j^{\prime}}^{e x p}$ is a weighted average of MFN tariff rates that a country $c^{\prime} s$ exporters in industry $j^{\prime}$ would face in their destination countries. ${ }^{16}$

\subsection{Estimation Results}

Baseline estimation results Table 2 and Table 3 present firm-level estimation results from our baseline specification using OLS and 2SLS, respectively, where the dependent variable is cash-to-asset ratio in log (multiplied by 100 for ease of interpretation). Column 1 reports estimation results from the baseline specification without any interaction terms, while columns 2,3, and 4 summarize estimation results from the augmented specification that includes interaction terms with tercile dummy variables based on total asset size.

A first look at the OLS estimation results in Table 2 suggests a significant within-firm increase in cash holdings, on average, in response to expanded export opportunities (column 1). As we add interaction terms with tercile dummy variables, no differential effects across firms are found (column 2). However, as country-year fixed effects are further added to control for macroeconomic shocks, the effect turns out to be concentrated among bigger firms (column 3). The results continue to hold after taking into account the effect of import competition. Interestingly, the export channel tends to dominate the import channel in that the point estimate on the former is about 10 times bigger than that of the latter (column 4).

Turning to Table 3 for 2SLS estimation results whereby the country-sector-level trade shock measures are instrumented by the average values in the other advanced economies, qualitatively identical results to those from OLS estimation are found. The first stage regression result in the bottom panel supports the strength of the instrumental variable- the substantial predictive power of instrumental variables from the peer country group's trade with China for a given country's export shock is confirmed. The second stage regression results in the upper panel further reveals that the coefficient estimates on the export shock variable from 2SLS estimator tend to be significantly greater in absolute terms than those from OLS estimator, suggesting that our instrumental variable strategy could partly correct for attenuation bias-due to measurement errors particularly in export shock variablesas well as omitted variable bias that would push the relationship negatively-reflecting for instance forces that discourage investment of domestic firms for precautionary reasons

\footnotetext{
${ }^{16}$ The weight used in calculating export MFN tariff rate is based on the share of exports by destination countries in each four-digit sector in the initial year.
} 
and hence, reduce their exports to China but boost their cash holdings.

The size of the estimated coefficient in column (4) implies that, conditional on all other macroeconomic and firm-level factors affecting cash holdings proportionately across firms, a 1 percentage point increase in export opportunities to China raises cash-to-asset ratio by around 8 percent more for largest firms compared to average firms in that country and year, whereas smallest firms actually reduce cash-to-asset ratio by around 5 percent relative to average firms in a given country-year. A simple back-of-the-envelope calculation suggests that globalization-led growth in export opportunities explains around 25 percent of the differential growth in cash holdings between bottom and top tercile firms over the period 2000-2011 for US firms, with the magnitude ranging from 10 percent for French firms to 86 percent for German firms. On the other hand, the import channel yields much smaller and nosier estimates, possibly reflecting offsetting forces of increased foreign competition on innovation activity such as the 'Schumpeterian' force versus the 'escape competition' force proposed in Aghion, Bloom, Blundell, Griffith and Howitt (2005).

Figure 12 illustrates this differential effect stemming from the export channel (as reported in column 2 in Table 3), by plotting the reduced-form correlation between cash ratio and the China export shock for large and small firms, conditional on other explanatory variables in the baseline regression. While the positive correlation is also found for firms in the bottom tercile of the asset size distribution, the slope is steepest for the top tercile firms. To the extent that firm size is a valid proxy for firm-level productivity, such heterogeneity in the degree of the export channel on cash holdings is consistent with the model prediction. ${ }^{17}$ Since the regressions control for firm fixed effects as well as sales and operating cash flows, we stress that the impact on cash holdings is not mechanically driven by increased profitability.

Alternative trade shock measures One potential concern about our baseline estimation strategy that exploits sector-level trade shocks stemming from China is that trade shock measures might be contaminated by other types of sector-year-level variation such as common technological growth trends. To check robustness of our baseline results to such concerns, we first tweak the underlying original trade shock measure (that was scaled by total output) to one scaled by total exports in each country-sector-year. This basically al-

\footnotetext{
${ }^{17}$ Similar differences in slopes are also found using the other proxies for firm productivity (average labor productivity, foreign sales share, and profitability).
} 
lows us to construct trade shock measures at the four-digit sector level, which in turn enables us to construct firm-level trade shocks by taking a weighted average across the two main four-digit sectors for each firm, with weights being the firm's sales share in its two main product segments. This alternative trade shock measures the role of China in each country-sector's overall trade, rather than overall production and absorption as in the baseline. With these more granular trade shock measures now varying across firms in a given country-sector, additional sector-year fixed effects can be added to control for common sector-year shocks across countries, effectively isolating trade shocks from other sources of sector-level shocks. Table 4 confirms that results are qualitatively identical to the baseline estimation results.

Alternatively, we also compute trade shock measures based on tariff rates at the countryindustry level. In particular, we compute a firm-specific measure of export tariff by using the lagged MFN tariff rate for each product (averaged across countries using trade weights at the beginning of the sample period), which is then weighted across products using the firm's sales share in its two main product segments defined at the four-digit level. A change in MFN tariffs in trading partner countries is arguably exogenous to an individual firm incorporated in the exporting country and hence presents a useful robustness check of our main results. To control for the effect of increased import competition resulting from domestic tariff liberalization, we also compute a corresponding measure using the import MFN tariff in each product category, weighted in a similar manner.

Estimation results for cash holdings using these alternative MFN tariff-based trade shocks are summarized in Table 5. Consistent with the baseline results using the China trade shock, we find that a decline in export tariffs faced by firms is associated with higher cash holdings for firms in the top tercile of the asset size in each country, but lower cash holdings for firms in the bottom tercile, both relative to average firms in a given countryyear. Once again, the impact is stronger through the export expansion rather than the import competition channel.

Confirming the innovation channel Next, we turn to testing the underlying mechanism of the model: firms raise cash holdings because of an increased incentive for R\&D and intangible investment in response to globalization shocks. This implies that the effect of globalization on cash holdings should be observed only among firms that do invest in 
innovation activity, which can be tested by checking the baseline estimation results for innovative and non-innovative firms separately. We define innovative firms as those who have ever spent on $R \& D$, and non-innovative firms as those who have never spent on $R \& D$ over the sample period. Column 1 in Table 6 reports the estimation results for innovative firms which are somewhat stronger than the baseline estimation results reported in column 4 in Table 3. On the other hand, column 2 in Table 6 shows that there is no significant effects from export or import shocks across all types of firms, which can be interpreted as a placebo test. ${ }^{18}$

Alternatively, noting that our model implies that an increase in cash holdings would be eventually translated to an increase in $R \& D$ spending, we can check the prediction by replacing the dependent variable in the baseline specification above with R\&D spendingto-sales ratio in log (multiplied by 100 for ease of interpretation). Column 3 in Table 6 presents the estimation results from our baseline specification using 2SLS estimator, which confirm the model-implied mechanism: the estimated heterogeneity of the export effect on innovation spending across firms mirrors the model's prediction for cash holdings. We find the presence of significant and sizable export channel effects particularly for bigger firms, whereas smallest firms actually reduce their R\&D investment relative to average firms in a given country-sector in response to positive export shocks.

In fact, our model's mechanism should apply to any activity by the firm that enhances its productivity in the long run but exposes it to higher liquidity risk in the short to medium run. Although R\&D is important category of such of innovation spending, it has been argued that a range of other types of expenditure represent investment in intangible organizational, social, and human capital (see Eisfeldt and Papanikolaou, 2013). These are for example spending in employee training, marketing, advertising, branding, IT upgrading etc., which tend to enhance profits in the long run, but due to their nature of being quasi-fixed cost, in the short-run introduce more disconnect between cost and revenues and thus, heighten liquidity risk. Data from income statement contain such expenditure (in addition to R\&D spending) in the variable SG\&A (selling, general and administration), although these may also capture other kinds of non-innovation related spending such as contribution to employee's social security funds. Column 4 in Table 6 reports the baseline regression results using the share of SG\&A spending (in percent of sales) as the depen-

\footnotetext{
${ }^{18}$ Our main findings broadly hold whether we set missing R\&D spending to zero or not.
} 
dent variable (multiplied by 100 for ease of interpretation), confirming the main result of positive and stronger effect of export shocks on broader innovation spending for bigger firms.

Confirming the liquidity risk channel We have shown that larger/more productive firms tend to increase cash holdings and spending on innovation and other quasi-overhead outlays when experiencing a positive export shock, consistent with our model's prediction. One final missing link is whether such firms indeed face increased liquidity risk subsequent to incurring such innovation spending to boost productivity, consistent with the model. We test this prediction in our empirical framework by estimating the differential effect of export shocks on the forward-looking volatility of cash flow from operations. That is, for each firm and year, we compute the standard deviation of cash flow from operation (scaled by assets) over the subsequent 4 years. The results are summarized in Table 8.

Indeed, as shown in column 1, larger firms experience significantly higher cash flow volatility (and thus, liquidity risk) than smaller firms when faced with the same export shock. Interestingly, columns 2-4 further show that this positive volatility differential in response to export shocks is driven only by those firms who also have a relatively high level of spending on innovation activities (that is, firms with relatively high spending on SG\&A as a share of sales). This is exactly what our model predicts, as increased overhead spending on activities associated with augmenting intangible capital drives the need for higher precautionary cash holdings. For the separately identified import shock, the effect is exactly opposite. That is, larger firms hit with the same import competition shock tend to experience less cash flow volatility going forward, consistent with the view that larger firms are more able to absorb negative domestic sale shocks from more intense import competition due to their ability to diversify and substitute across domestic and foreign markets (see e.g. Vannoorenberghe, 2012).

Alternative firm-level proxies Our baseline specification used firm size (total assets) as a proxy for firm-level productivity. Alternatively, we could consider labor productivity (sales per employee), export intensity (foreign sales in percent of total sales), or profitabil- 
ity (net income per employee) as alternative proxies for firm-level productivity. ${ }^{19}$ Table 9 summarizes the baseline regression using this set of alternative proxies for firm-level productivity. The overall results are found robust across different types of firm-level productivity measures.

Overall, our results have shown that firms respond to globalization shocks-especially those associated with expanding export opportunities-by raising cash holdings, and that this effect is consistent with stronger incentives for R\&D and intangible investment. Moreover, our results confirm that such patterns tend to hold more strongly for more productive firms, whether proxied by size, labor productivity, export intensity, or profitability. All of these findings are consistent with the model's prediction that incomplete pledgeability of returns to innovation, coupled with interim liquidity risk, creates demand for cash. The growing incentive to invest in innovation and other intangible capital associated with growing globalization can therefore explain part of the recent increase in corporate cash holdings worldwide. Next, we turn to checking the robustness of our main findings to other potential motives for cash holdings.

Controlling for other motives Noting that previous studies mostly focused on US firms where tax motive is proposed to be a major determinant of an increase in cash holdings (Foley et al. 2007), we check the possibility that our main findings are somehow driven by tax motives. Specifically, as an attempt to disentangle the tax motive from the globalization channel we propose in the model, we control directly for the effective tax rate (ETR) for a given firm, computed as the ratio of total taxes (both domestic and foreign) paid divided by pre-tax book income. This measure of ETR has been commonly used in the literature to measure the tax burden of a firm at a consolidated basis (e.g., Markle and Shackelford, 2012). The identifying assumption is that, once key firm characteristics (such as size, industry, cash flow) are controlled for, variation in ETR particularly between multinational and domestic firms, but also within a multinational firm over time reflects the degree of profit shifting and tax-minimization strategies-likely conducted by large, publicly-listed firms as those in our dataset. ${ }^{20}$ On top of that, we also control for the $M \& A$

\footnotetext{
${ }^{19}$ Unfortunately, our dataset is not well suited to estimate firm-level total factor productivity (TFP) due to incomplete data coverage on intermediate inputs.

${ }^{20}$ This is admittedly only a crude measure of the ex-post outcome of tax strategies: they include combined measure of domestic and foreign taxes, as well as current and deferred taxes that are reported in financial accounts. Changes in ETR can be also driven by changes in statutory tax rates over time and/or reflect the
} 
motive by including a dummy variable whether a firm acquired a new firm a year later in case globalization shocks might have increased a firm's appetite to acquire (particularly foreign) firms to enhance its global presence, which could in turn have incentivized firms to hold more cash to finance the acquisition. Similarly, since cash is also known to be frequently used for share buyback, we include a dummy variable indicating whether a firm conducted the share buyback program a year later.

The results of the main regressions that allow for alternative motives of cash holdings are summarized in Table 9. The signs of the coefficient estimates on the alternative channels are consistent with the above priors, and the estimated effects of the buyback and acquisition motives for cash holdings are particularly strong. However, none of the alternative channels turn out to affect the estimates of our main differential effect of export shocks, which retains statistical significance and similar magnitudes to the baseline results across all proxies of productivity differentials.

\section{Conclusion}

The last quarter century was an era of significant shifts in the global economy through trade, technology and political changes, including the transformation of global labor markets following the entry of China, India and countries of the former Eastern bloc into the world economy in the early 1990's. The period since the 2000's saw an acceleration of globalization following China's accession to the WTO and rapid increases in emerging markets' investment in infrastructure and education that led to a surge in their integration into world markets (Obstfeld, 2016). At the same time, large corporations across the world have become net lenders to the rest of the economy, accumulating unprecedented levels of cash on their balance sheets and investing increasingly in intangible capital.

In this paper, we show that these macro and micro-level trends are closely related. This occurs, as illustrated by our model, when globalization allows the most innovative and productive firms to capture a larger market, at the same time as higher innovation intensity exposes those firm to more liquidity risk in the interim, leading to more demand for cash arising from an optimal contract with outside investors. Using a comprehensive dataset covering the vast majority of publicly listed firms in five G7 economies, we provide progressivity of the tax regime. 
evidence in support of the proposed mechanism, which could explain, on average, around 33 percent of the observed growth differential in cash holdings across firms in these countries. Given that globalization will advance in the long run, our paper's findings imply that firms' liquidity demand may increase as well, possibly increasing the demand for safe assets and entrenching the high corporate saving rates in many advanced economies. Conversely, the degree of financial frictions and quality of corporate governance structures which shape the ability of firms to obtain external and internal liquidity, can be of great importance for the process of exporter selection and the extent to which firms can reap the gains from global integration. 


\section{References}

Aghion, P., Bloom, N., Blundell, R., Griffith, R. and Howitt, P., 2005. "Competition and Innovation: an Inverted-U Relationship." Quarterly Journal of Economics, 120(2), pp.701728.

Aghion, P., Angeletos, G.M., Banerjee, A. and Manova, K., 2010. "Volatility and growth: Credit constraints and the composition of investment." Journal of Monetary Economics, 57(3), pp.246-265.

Aghion, P., Bergeaud, A., Lequien, M. and Melitz, M.J., 2018. “The impact of exports on innovation: Theory and evidence." National Bureau of Economic Research WP No. 24600.

Ahn, J. and Duval R., 2017. "Trading with China: Productivity Gains, Job Losses", Economics Letters, 160, pp.38-42.

Alexander, L. and Eberly, J., 2016, "Investment Hollowing Out", paper prepared for the Seventeenth Annual Jacques Polak Research Conference at the IMF, November 2016.

Armenter, R., 2012. "The rise of corporate savings." Philadelphia Business Review: The Federal Reserve Bank of Philadelphia.

Armenter, R., Hnatkovska, V., 2017. "Taxes and Capital Structure: Understanding Firms' Savings", Journal of Monetary Economics, forthcoming.

Autor, D.H., Dorn, D. and Hanson, G.H., 2013. "The China syndrome: Local labor market effects of import competition in the United States." The American Economic Review, 103(6), pp.2121-2168.

Autor, D., Dorn, D., Hanson, G.H., Pisano, G. and Shu, P., 2016. "Foreign competition and domestic innovation: Evidence from US patents" NBER Working Paper No. 22879, National Bureau of Economic Research.

Azar, J.A., Kagy, J.F. and Schmalz, M.C., 2016. "Can changes in the cost of carry explain the dynamics of corporate cash holdings?" The Review of Financial Studies, 29(8), pp.2194-2240.

Bates, T.W., Kahle, K.M. and Stulz, R.M., 2009. “Why do US firms hold so much more cash than they used to?" Journal of Finance, 64(5), pp.1985-2021.

Begenau, J. and Palazzo, B., 2016. "Firm selection and corporate cash holdings." Working Paper.

Bernard, A.B., Jensen, J.B., Redding, S.J. and Schott, P.K., 2007. "Firms in international trade." Journal of Economic Perspectives, 21(3), pp.105-130.

Bernard, A.B., Jensen, J.B., and Schott, P.K., 2009. “Importers, Exporters and Multinationals: A Portrait of Firms in the U.S. that Trade Goods, in Producer Dynamics: New Evidence from Micro Data, ed. by T. Dunne, J. B. Jensen, and M. J. Roberts. Chicago University Press, Chicago.

Bloom, N., Draca, M., and Van Reenen, J., 2016. "Trade Induced Technical Change? The Impact of Chinese Imports on Innovation, IT and Productivity." Review of Economic Studies, 83(1), pp.87-117. 
Bonfiglioli, A., Crino, R. and Gancia, G., 2017. "Betting on exports: trade and endogenous heterogeneity." The Economic Journal, 128(609), pp.612-651.

Brown, J.R. and Petersen, B.C., 2011. "cash holdings and R\&D smoothing." Journal of Corporate Finance, 17(3), pp.694-709.

Bustos, P., 2011. "Trade Liberalization, Exports, and Technology Upgrading: Evidence on the Impact of MERCOSUR on Argentinian Firms." American Economic Review, 101(1), pp.304-340.

Chaney, T., 2011. "Liquidity Constrained Exporters." Journal of Economic Dynamics and Control, 72(C), pp.141-154.

Chen, P., Karabarbounis, L. and Neiman, B., 2017. "The global rise of corporate saving." Journal of Monetary Economics, 89, pp.1-19.

Coelli, F., , Moxnes, A. and Ulltveit-Moe, A.H., 2017. “Better, Faster, Stronger: Global Innovation and Trade Liberalization" NBER Working Paper 22647.

Corrado, C.A. and Hulten, C.R., 2010. "How Do You Measure a Technological Revolution?" American Economic Review, 100(2), pp.99-104.

Dao, M.C. and Maggi, C., 2018, "The rise in corporate saving and cash holdings in advanced economies: aggregate and firm-level trends", IMF Working Paper, forthcoming.

Dittmar, A., Mahrt-Smith, J. and Servaes, H., 2003. "International corporate governance and corporate cash holdings.", Journal of Financial and Quantitative analysis, 38(1), pp.111133.

Eisfeldt, A.L. and Papanikolaou, D., 2013. "Organization capital and the cross-section of expected returns." Journal of Finance, 68(4), pp.1365-1406.

Falato, A., Kadyrzhanova, D. and Sim, J., 2013. “Rising intangible capital, shrinking debt capacity, and the US corporate savings glut.", FEDS Working Paper 2013-67.

Foley, C.F., Hartzell, J.C., Titman, S. and Twite, G., 2007. “Why do firms hold so much cash? A tax-based explanation." Journal of Financial Economics, 86(3), pp.579-607.

Holmström, B. and Tirole, J., 1998. "Private and public supply of liquidity.", Journal of Political Economy, 106(1), pp.1-40.

International Monetary Fund (IMF), 2017. External Sector Report. July 2017: Washington DC.

Lev, B. and Radhakrishnan, S., 2005. "The valuation of organization capital." In Measuring capital in the new economy (pp. 73-110). University of Chicago Press.

Lileeva, A. and Trefler, D., 2010. “Improved Access to Foreign Markets Raises Plant-level ProductivityFor Some Plants." Quarterly Journal of Economics, 125(3), pp.1051-1099.

Lyandres, E. and Palazzo, B., 2016. "cash holdings, Competition, and Innovation." Journal of Financial and Quantitative Analysis, 51(6), pp.1823-1861. 
Manova, K., 2013. “Credit Constraints, Heterogeneous Firms, and International Trade." Review of Economic Studies, 80(2), pp.711-744.

Markle, K. and Shackelford, D., 2012 "Cross-Country Comparisons of Corporate Income Taxes." National Tax Journal, 65(3), pp.493-527.

Mayer, T., Melitz, M.J. and Ottaviano, G.I., 2016. "Product mix and firm productivity responses to trade competition", National Bureau of Economic Research WP No. 22433.

Melitz, M.J., 2003. "The impact of trade on intra industry reallocations and aggregate industry productivity." Econometrica, 71(6), pp.1695-1725.

Obstfeld, M. 2016. “Get on Track with Trade. In Finance \& Development 53 (4).

Pinkowitz, L., Stulz, R.M. and Williamson, R., 2016. “Do US firms hold more cash than foreign firms do?" The Review of Financial Studies, 29(2), pp.309-348.

Srivastava, A. and Tse, S., 2016. "Why are successive cohorts of listed firms persistently riskier?", European Financial Management Journal 22(5): pp. 9571000.

Subramanian, A. and Kessler, M., 2013. "The hyperglobalization of trade and its future", PIIE Working Paper 13-6.

Tirole, J., 2006. The Theory of Corporate Finance, Princeton University Press.

Vannoorenberghe, G., 2012. "Firm-level volatility and exports', Journal of International Economics, 86(1), pp.57-67.

Verhoogen, E., 2008. “Trade, Quality Upgrading, and Wage Inequality in the Mexican Manufacturing Sector" The Quarterly Journal of Economics, 123 (2), pp. 489-530. 
Table 1: Average of yearly medians for each country.

\begin{tabular}{lrrrrrrrrr}
\hline country & CashTA & Size & MB & Leverage & CF & RD2Sales & intangTA & Dividend & obs \\
\hline FRANCE & .108 & 103 & 1.238 & .178 & .072 & .033 & .112 & .538 & 13121 \\
GERMANY & .094 & 125 & 1.263 & .152 & .076 & .032 & .06 & .469 & 12602 \\
JAPAN & .15 & 273 & 1.01 & .205 & .052 & .012 & .006 & .81 & 65323 \\
UK & .089 & 80 & 1.38 & .131 & .073 & .03 & .118 & .559 & 24598 \\
USA & .115 & 202 & 1.547 & .151 & .075 & .078 & .108 & .228 & 83684 \\
\hline
\end{tabular}

Source: Thomson Reuters Worldscope. CashT A is the ratio of Cash and short-term investment over total book assets; $M B$ is the market-to-book ratio; Size is expressed in Mn US Dollar; $C F$ stands for cash flow in percent of asset, RD2Sales is the median spending on $\mathrm{R} \& \mathrm{D}$ in percent of sales among firms with positive R\&D spending (the unconditional median is zero), intang $T A$ is the share of declared intangibles to assets ratio; Dividend is the share of firms that pay dividend; obs is the total number of firm-year observations.

Table 2: Globalization and Cash Holding: China Shocks; OLS

\begin{tabular}{|c|c|c|c|c|}
\hline & $\begin{array}{c}(1) \\
\text { No interaction }\end{array}$ & $\begin{array}{c}(2) \\
X=S I Z E\end{array}$ & $\begin{array}{c}(3) \\
\mathrm{X}=\mathrm{SIZE}\end{array}$ & $\begin{array}{c}(4) \\
X=S I Z E\end{array}$ \\
\hline expSHOCK & $\begin{array}{c}4.386^{* * *} \\
(0.581)\end{array}$ & $\begin{array}{c}4.228^{* * *} \\
(0.536)\end{array}$ & $\begin{array}{c}-2.851^{* * *} \\
(0.785)\end{array}$ & $\begin{array}{c}-2.386^{* * *} \\
(0.756)\end{array}$ \\
\hline expSHOCK_X2 & & $\begin{array}{l}-0.186 \\
(0.498)\end{array}$ & $\begin{array}{c}1.393^{* * *} \\
(0.519)\end{array}$ & $\begin{array}{l}0.918^{*} \\
(0.516)\end{array}$ \\
\hline expSHOCK_X3 & & $\begin{array}{c}0.419 \\
(0.719)\end{array}$ & $\begin{array}{c}4.389^{* * *} \\
(0.857)\end{array}$ & $\begin{array}{c}3.548^{* * *} \\
(0.814)\end{array}$ \\
\hline impSHOCK & & & & $\begin{array}{l}-0.146^{* *} \\
(0.0642)\end{array}$ \\
\hline impSHOCK_X2 & & & & $\begin{array}{l}0.210^{* * *} \\
(0.0789)\end{array}$ \\
\hline impSHOCK_X3 & & & & $\begin{array}{l}0.407^{* * *} \\
(0.0918)\end{array}$ \\
\hline Firm FE & $\bar{Y}$ & $\bar{Y}$ & $\mathrm{Y}$ & $\mathrm{Y}$ \\
\hline Country-year FE & $\mathrm{N}$ & $\mathrm{N}$ & Y & Y \\
\hline $\mathrm{R} 2$ & 0.720 & 0.720 & 0.732 & 0.732 \\
\hline $\mathrm{N}$ & 57172 & 57172 & 57172 & 57172 \\
\hline
\end{tabular}

Notes: This table presents results of panel OLS regressions examining the effect of export and import shocks vis-à-vis China on cash holding. Dependent variable is cash holding-to-assets ratio in log. All columns include firm fixed effects as well as other firm-level controls such as total sales, operating cash flow. Additional countryyear fixed effects are inlcuded in columns 3-4. Tercile dummy variables based on total assets are also included but not reported in columns 2-4. Standard errors in parentheses are clustered at country-sector-year level. $\left({ }^{*} p<0.10,{ }^{* *} p<0.05,{ }^{* * *}\right.$ $p<0.01)$ 
Table 3: Globalization and Cash Holding: China Shocks; 2SLS

\begin{tabular}{|c|c|c|c|c|}
\hline & $\begin{array}{c}(1) \\
\text { No interaction }\end{array}$ & $\begin{array}{c}(2) \\
X=\text { SIZE }\end{array}$ & $\begin{array}{c}(3) \\
X=S I Z E\end{array}$ & $\begin{array}{c}(4) \\
X=S I Z E\end{array}$ \\
\hline expSHOCK & $\begin{array}{c}8.209^{* * *} \\
(0.758)\end{array}$ & $\begin{array}{c}7.229^{* * *} \\
(0.987)\end{array}$ & $\begin{array}{c}-5.435^{* * *} \\
(1.224)\end{array}$ & $\begin{array}{c}-5.187^{* * *} \\
(1.646)\end{array}$ \\
\hline expSHOCK_X2 & & $\begin{array}{c}-0.264 \\
(1.280)\end{array}$ & $\begin{array}{l}3.131^{* *} \\
(1.342)\end{array}$ & $\begin{array}{c}2.769 \\
(1.967)\end{array}$ \\
\hline expSHOCK_X3 & & $\begin{array}{l}2.752^{*} \\
(1.483)\end{array}$ & $\begin{array}{c}8.177^{* * *} \\
(1.456)\end{array}$ & $\begin{array}{c}8.042^{* * *} \\
(2.098)\end{array}$ \\
\hline impSHOCK & & & & $\begin{array}{c}-0.117 \\
(0.193)\end{array}$ \\
\hline impSHOCK_X2 & & & & $\begin{array}{c}0.101 \\
(0.244)\end{array}$ \\
\hline impSHOCK_X3 & & & & $\begin{array}{l}0.0212 \\
(0.268)\end{array}$ \\
\hline $\begin{array}{l}\text { First stage } \\
\exp S H O C K(I V) \\
\text { F-stat. }\end{array}$ & $\begin{array}{c}\text { Dep. var: expSHOCK } \\
1.248^{* * *}[0.058] \\
40.9\end{array}$ & & & \\
\hline Firm FE & $\mathrm{Y}$ & $\mathrm{Y}$ & $\mathrm{Y}$ & $\mathrm{Y}$ \\
\hline Country-year FE & $\mathrm{N}$ & $\mathrm{N}$ & $\mathrm{Y}$ & $\mathrm{Y}$ \\
\hline $\mathrm{N}$ & 57172 & 57172 & 57172 & 57172 \\
\hline
\end{tabular}

Notes: This table presents results of panel 2SLS regressions examining the effect of export and import shocks vis-à-vis China on cash holding. All columns include firm fixed effects as well as other firm-level controls such as total sales, operating cash flow. Additional country-year fixed effects are inlcuded in columns 3-4. Tercile dummy variables based on total assets are also included but not reported in columns 2-4. Standard errors in parentheses are clustered at country-sector-year level. $\left({ }^{*} p<0.10,{ }^{* *} p<0.05,{ }^{* * *} p<0.01\right)$ 
Table 4: Globalization and Cash Holding: Firm-level China Shocks; 2SLS

\begin{tabular}{|c|c|c|c|c|}
\hline & $\begin{array}{c}(1) \\
\text { No interaction }\end{array}$ & $\begin{array}{c}(2) \\
X=\text { SIZE }\end{array}$ & $\begin{array}{c}(3) \\
X=\text { SIZE }\end{array}$ & $\begin{array}{c}(4) \\
X=S I Z E\end{array}$ \\
\hline expSHOCK & $\begin{array}{c}5.001^{* * *} \\
(0.853)\end{array}$ & $\begin{array}{c}4.467^{* * *} \\
(1.019)\end{array}$ & $\begin{array}{l}-0.729 \\
(1.213)\end{array}$ & $\begin{array}{l}-0.815 \\
(1.376)\end{array}$ \\
\hline $\operatorname{expSHOCKX2}$ & & $\begin{array}{c}-0.119 \\
(0.929)\end{array}$ & $\begin{array}{c}1.418 \\
(0.895)\end{array}$ & $\begin{array}{c}1.424 \\
(0.930)\end{array}$ \\
\hline $\operatorname{expSHOCKX3}$ & & $\begin{array}{c}1.259 \\
(1.035)\end{array}$ & $\begin{array}{c}4.221^{* * *} \\
(1.052)\end{array}$ & $\begin{array}{c}3.856^{* * *} \\
(1.054)\end{array}$ \\
\hline impSHOCK & & & & $\begin{array}{l}-0.335 \\
(0.247)\end{array}$ \\
\hline impSHOCK_X2 & & & & $\begin{array}{c}-0.0444 \\
(0.193)\end{array}$ \\
\hline impSHOCK_X3 & & & & $\begin{array}{c}0.302 \\
(0.284)\end{array}$ \\
\hline $\begin{array}{l}\text { First stage } \\
\exp S H O C K(I V) \\
\text { F-stat. }\end{array}$ & $\begin{array}{c}\text { Dep. var: expSHOCK } \\
0.861^{* * *}[0.131] \\
43.4\end{array}$ & & & \\
\hline Firm FE & $\mathrm{Y}$ & $\mathrm{Y}$ & $\mathrm{Y}$ & $\mathrm{Y}$ \\
\hline Country-year FE & $\mathrm{N}$ & $\mathrm{N}$ & $\mathrm{Y}$ & $\mathrm{Y}$ \\
\hline Sector-year FE & $\mathrm{N}$ & $\mathrm{N}$ & Y & Y \\
\hline $\mathrm{N}$ & 63600 & 63600 & 63578 & 63567 \\
\hline
\end{tabular}

Notes: This table presents results of panel 2SLS regressions examining the effect of firmlevel export and import shocks vis-à-vis China on cash holding. Dependent variable is cash holding-to-assets ratio in log. All columns include firm fixed effects as well as other firmlevel controls such as total sales, operating cash flow. Additional country-year and sectoryear fixed effects are inlcuded in columns 3-4. Tercile dummy variables based on total assets are also included but not reported in columns 2-4. Standard errors in parentheses are clustered at two levels (country-year and sector-year). $\left({ }^{*} p<0.10,{ }^{* *} p<0.05,{ }^{* * *} p<0.01\right.$ ) 
Table 5: Globalization and Cash Holding: Tariff; OLS

\begin{tabular}{lcccc}
\hline \hline & $(1)$ & $(2)$ & $(3)$ & $(4)$ \\
& No interaction & X=SIZE & X=SIZE & X=SIZE \\
\hline expMFN & $-3.106^{* * *}$ & $-1.753^{* * *}$ & $1.330^{* * *}$ & $1.008^{* *}$ \\
& $(0.602)$ & $(0.541)$ & $(0.467)$ & $(0.476)$ \\
expMFN_X2 & & $-1.393^{* *}$ & $-1.320^{* * *}$ & -0.837 \\
& & $(0.531)$ & $(0.476)$ & $(0.622)$ \\
expMFN_X3 & & $-2.058^{* * *}$ & $-2.063^{* * *}$ & $-1.655^{* *}$ \\
& & $(0.761)$ & $(0.610)$ & $(0.675)$ \\
impMFN & & & & 0.636 \\
& & & & $(0.820)$ \\
impMFN_X2 & & & & $-1.788^{*}$ \\
& & & & $(0.965)$ \\
impMFN_X3 & & & & $-1.735^{*}$ \\
& & & & $(0.911)$ \\
\hline Firm FE & & & & \\
Country-year FE & $\mathrm{Y}$ & $\mathrm{N}$ & $\mathrm{Y}$ & $\mathrm{Y}$ \\
Sector-year FE & $\mathrm{N}$ & $\mathrm{N}$ & $\mathrm{Y}$ & $\mathrm{Y}$ \\
R2 & 0.713 & 0.713 & 0.731 & 0.730 \\
N & 45873 & 45873 & 45854 & 44162 \\
\hline \hline
\end{tabular}

Notes: This table presents results of panel OLS regressions examining the effect of export and import tariff changes on cash holding. Dependent variable is cash holding-to-assets ratio in log. All columns include firm fixed effects as well as other firm-level controls such as total sales, operating cash flow. Additional country-year and sector-year fixed effects are included in columns 3-4. Tercile dummy variables based on total assets are also included but not reported in columns 2-4. Standard errors in parentheses are clustered at two levels (country-year and sector-year). ( ${ }^{*}$ $\left.p<0.10,{ }^{* *} p<0.05,{ }^{* * *} p<0.01\right)$ 
Table 6: The Underlying Channel of Globalization and Cash Holding: China Shocks; 2SLS

\begin{tabular}{|c|c|c|c|c|}
\hline & $\begin{array}{c}(1) \\
X=S I Z E \\
\text { innovative firms }\end{array}$ & $\begin{array}{c}(2) \\
\mathrm{X}=\mathrm{SIZE} \\
\text { non-innovative firms }\end{array}$ & $\begin{array}{c}(3) \\
X=S I Z E \\
\text { DV:R\&D spending }\end{array}$ & $\begin{array}{c}(4) \\
X=S I Z E \\
\text { DV:SG\&A spending }\end{array}$ \\
\hline expSHOCK & $\begin{array}{c}-6.977^{* * *} \\
(1.760)\end{array}$ & $\begin{array}{c}3.537 \\
(5.963)\end{array}$ & $\begin{array}{c}-11.06^{* * *} \\
(2.960)\end{array}$ & $\begin{array}{c}-7.220^{* * *} \\
(1.489)\end{array}$ \\
\hline expSHOCK_X2 & $\begin{array}{l}2.957 \\
(2.376)\end{array}$ & $\begin{array}{l}8.067 \\
(7.624)\end{array}$ & $\begin{array}{c}11.74^{* * *} \\
(3.519)\end{array}$ & $\begin{array}{c}8.940^{* * *} \\
(1.642)\end{array}$ \\
\hline expSHOCK_X3 & $\begin{array}{c}8.747^{* * *} \\
(2.164)\end{array}$ & $\begin{array}{l}17.45 \\
(10.80)\end{array}$ & $\begin{array}{c}19.35^{* * *} \\
(3.710)\end{array}$ & $\begin{array}{c}11.56^{* * *} \\
(1.839)\end{array}$ \\
\hline impSHOCK & $\begin{array}{r}-0.0276 \\
(0.248)\end{array}$ & $\begin{array}{l}-0.0784 \\
(0.349)\end{array}$ & $\begin{array}{l}1.409^{* *} \\
(0.561)\end{array}$ & $\begin{array}{l}0.494^{* *} \\
(0.194)\end{array}$ \\
\hline impSHOCK_X2 & $\begin{array}{r}-0.0926 \\
(0.400)\end{array}$ & $\begin{array}{l}0.0996 \\
(0.428)\end{array}$ & $\begin{array}{l}-0.843 \\
(0.715)\end{array}$ & $\begin{array}{c}-0.434^{*} \\
(0.223)\end{array}$ \\
\hline impSHOCK_X3 & $\begin{array}{l}-0.230 \\
(0.353)\end{array}$ & $\begin{array}{l}0.0977 \\
(0.505)\end{array}$ & $\begin{array}{c}-2.056^{* * *} \\
(0.751)\end{array}$ & $\begin{array}{c}-0.630^{* *} \\
(0.259)\end{array}$ \\
\hline Firm FE & $\mathrm{Y}$ & $\mathrm{Y}$ & $\mathrm{Y}$ & $\mathrm{Y}$ \\
\hline Country-year FE & $\mathrm{Y}$ & $\mathrm{Y}$ & $\mathrm{Y}$ & $\mathrm{Y}$ \\
\hline $\mathrm{N}$ & 43782 & 13390 & 36782 & 51474 \\
\hline
\end{tabular}

Notes: This table presents results of panel 2SLS regressions confirming the innovation channel through which export and import shocks vis-à-vis China affect cash holding. Dependent variable in columns 1 and 2 is cash holding-to-assets ratio in log, whille depedent variable in columns 3 and 4 is R\&D spending-to-sales ratio and SG\&A spending-to-sales ratio, respectively, both in log. Column 1 includes innovative firms only and column 2 includes non-innovative firms only. All columns include firm- and country-year fixed effects as well as other firm-level controls such as total sales, operating cash flow. Tercile dummy variables based on total assets are also included but not reported. Standard errors in parentheses are clustered at country-sector-year level. $\left({ }^{*} p<0.10\right.$, $\left.{ }^{* *} p<0.05,{ }^{* * *} p<0.01\right)$ 
Table 7: Globalization and Cash Holding: China Shocks; 2SLS; Alternative firm proxies

\begin{tabular}{lcccccc}
\hline \hline & $(1)$ & $(2)$ & $(3)$ & $(4)$ & $(5)$ & $(6)$ \\
& X=LP & X=LP & X=EXP & X=EXP & X=NIPE & X=NIPE \\
\hline expSHOCK & $-3.513^{* * *}$ & $-4.436^{* * *}$ & $-10.89^{* * *}$ & $-13.34^{* * *}$ & $-7.726^{* * *}$ & $-5.763^{* *}$ \\
& $(1.030)$ & $(1.716)$ & $(2.357)$ & $(3.420)$ & $(1.959)$ & $(2.907)$ \\
expSHOCK_X2 & $2.410^{*}$ & 2.919 & $8.122^{* * *}$ & $9.867^{* *}$ & 5.244 & -2.783 \\
& $(1.421)$ & $(2.251)$ & $(2.894)$ & $(4.044)$ & $(3.982)$ & $(6.850)$ \\
expSHOCK_X3 & $12.70^{* * *}$ & $15.39^{* * *}$ & $9.039^{* * *}$ & $12.40^{* * *}$ & $19.04^{* * *}$ & $20.54^{* * *}$ \\
& $(2.177)$ & $(3.209)$ & $(2.197)$ & $(3.509)$ & $(2.854)$ & $(3.875)$ \\
impSHOCK & & 0.291 & & & & \\
& & $(0.380)$ & & $(0.341$ & & -0.383 \\
impSHOCK_X2 & & -0.237 & & -0.287 & & $(0.517)$ \\
& & $(0.420)$ & & $(0.340)$ & & 1.740 \\
impSHOCK_X3 & & $-0.819^{*}$ & & -0.678 & & -0.289 \\
& & $(0.496)$ & & $(0.418)$ & & $(0.560)$ \\
\hline Firm FE & $\mathrm{Y}$ & $\mathrm{Y}$ & $\mathrm{Y}$ & $\mathrm{Y}$ & $\mathrm{Y}$ & $\mathrm{Y}$ \\
Country-year FE & $\mathrm{Y}$ & $\mathrm{Y}$ & $\mathrm{Y}$ & $\mathrm{Y}$ & $\mathrm{Y}$ & $\mathrm{Y}$ \\
$\mathrm{N}$ & 54929 & 54929 & 40059 & 40059 & 54911 & 54911 \\
\hline \hline
\end{tabular}

Notes: This table presents results of panel 2SLS regressions examining the effect of export and import shocks vis-à-vis China on cash holding for innovative firms. Dependent variable is cash holding-to-assets ratio in log. All columns include firm- and country-year fixed effects as well as other firm-level controls such as total sales, operating cash flow. Tercile dummy variables included but not reported in this table is based on labor productivity (columns 1-2), the share of foreign sales in total sales (columns 3-4), and net income per employee (columns 5-6). Standard errors in parentheses are clustered at country-sectoryear level. $\left({ }^{*} p<0.10,{ }^{* *} p<0.05,{ }^{* * *} p<0.01\right)$ 
Table 8: Cash flow volatility and globalization shocks

\begin{tabular}{lcccc}
\hline \hline & $(1)$ & $(2)$ & $(3)$ & $(4)$ \\
& All firms & SG\&A $<$ median & SG\&A $>$ median & SG\&A $>75$ thpctile \\
\hline exp_SHOCK & $-3.696^{* *}$ & $-0.401^{* *}$ & $-7.409^{*}$ & $-31.26^{*}$ \\
& $(1.862)$ & $(0.172)$ & $(4.132)$ & $(17.53)$ \\
exp_SHOCK_X2 & $3.506^{* *}$ & 0.192 & $7.143^{*}$ & $29.29^{*}$ \\
& $(1.785)$ & $(0.210)$ & $(3.942)$ & $(16.99)$ \\
exp_SHOCK_X3 & $3.440^{*}$ & 0.152 & $7.043^{*}$ & $30.72^{*}$ \\
& $(1.883)$ & $(0.193)$ & $(4.218)$ & $(17.62)$ \\
imp_SHOCK_X1 & $0.477^{*}$ & $0.0361^{*}$ & 1.045 & $4.879^{*}$ \\
& $(0.282)$ & $(0.0197)$ & $(0.671)$ & $(2.941)$ \\
imp_SHOCK_X2 & $-0.498^{*}$ & 0.00941 & -1.091 & -4.616 \\
& $(0.290)$ & $(0.0327)$ & $(0.694)$ & $(2.894)$ \\
imp_SHOCK_X3 & $-0.498^{*}$ & -0.0232 & -1.065 & $-5.069^{*}$ \\
& $(0.297)$ & $(0.0429)$ & $(0.688)$ & $(3.047)$ \\
\hline Firm FE & $\mathrm{Y}$ & $\mathrm{Y}$ & $\mathrm{Y}$ & $\mathrm{Y}$ \\
Country-year FE & $\mathrm{Y}$ & $\mathrm{Y}$ & $\mathrm{Y}$ & $\mathrm{Y}$ \\
$\mathrm{N}$ & 36430 & 16997 & 18901 & 10845 \\
\hline \hline
\end{tabular}

Notes: This table presents results of panel 2SLS regressions examining the effect of export and import shocks vis-à-vis China on cash flow volatility, defined as the standard deviation of cash flow/asset rate over the subsequent 5-year window. Dependent variable is standard deviation of cash flow/asset ratio over the subsequent 5 years. All columns include firm- and country-year fixed effects as well as other firm-level controls such as total sales, operating cash flow. Tercile dummy variables included but not reported in this table is based on firm's total assets (size). Standard errors in parentheses are clustered at country-sector-year level. $\left({ }^{*} p<0.10,{ }^{* *} p<0.05,{ }^{* * *} p<0.01\right)$ 
Table 9: Globalization and Cash Holding: China Shocks; 2SLS; Controlling for Other Motives

\begin{tabular}{|c|c|c|c|c|}
\hline & $\begin{array}{c}(1) \\
X=\text { SIZE }\end{array}$ & $\begin{array}{c}(2) \\
X=\mathrm{LP}\end{array}$ & $\begin{array}{c}(3) \\
X=E X P\end{array}$ & $\begin{array}{c}(4) \\
X=\text { NIPE }\end{array}$ \\
\hline expSHOCK & $\begin{array}{c}-3.112 \\
(2.183)\end{array}$ & $\begin{array}{c}-1.812 \\
(1.690)\end{array}$ & $\begin{array}{c}-12.61^{* * *} \\
(3.913)\end{array}$ & $\begin{array}{c}1.867 \\
(3.576)\end{array}$ \\
\hline expSHOCK_X2 & $\begin{array}{c}1.341 \\
(2.362)\end{array}$ & $\begin{array}{c}2.161 \\
(2.187)\end{array}$ & $\begin{array}{c}13.20^{* * *} \\
(4.481)\end{array}$ & $\begin{array}{l}-11.81 \\
(7.389)\end{array}$ \\
\hline expSHOCK_X3 & $\begin{array}{l}5.163^{* *} \\
(2.360)\end{array}$ & $\begin{array}{l}6.138^{* *} \\
(2.750)\end{array}$ & $\begin{array}{c}11.19^{* * *} \\
(3.879)\end{array}$ & $\begin{array}{c}8.744^{* * *} \\
(2.949)\end{array}$ \\
\hline impSHOCK & $\begin{array}{l}-0.377 \\
(0.239)\end{array}$ & $\begin{array}{l}0.0844 \\
(0.386)\end{array}$ & $\begin{array}{c}0.180 \\
(0.346)\end{array}$ & $\begin{array}{l}-0.438 \\
(1.138)\end{array}$ \\
\hline impSHOCK_X2 & $\begin{array}{l}0.497^{*} \\
(0.286)\end{array}$ & $\begin{array}{l}-0.205 \\
(0.426)\end{array}$ & $\begin{array}{l}-0.300 \\
(0.349)\end{array}$ & $\begin{array}{c}1.375 \\
(1.562)\end{array}$ \\
\hline impSHOCK_X3 & $\begin{array}{c}0.286 \\
(0.283)\end{array}$ & $\begin{array}{l}-0.134 \\
(0.433)\end{array}$ & $\begin{array}{l}-0.241 \\
(0.394)\end{array}$ & $\begin{array}{c}-0.0344 \\
(1.197)\end{array}$ \\
\hline EffectiveTaxRate & $\begin{array}{c}-0.0882 \\
(0.431)\end{array}$ & $\begin{array}{c}-0.0971 \\
(0.436)\end{array}$ & $\begin{array}{c}0.196 \\
(0.272)\end{array}$ & $\begin{array}{c}-0.0796 \\
(0.460)\end{array}$ \\
\hline Acquisition & $\begin{array}{c}9.399^{* * *} \\
(1.445)\end{array}$ & $\begin{array}{c}9.187^{* * *} \\
(1.459)\end{array}$ & $\begin{array}{c}10.65^{* * *} \\
(1.570)\end{array}$ & $\begin{array}{c}9.118^{* * *} \\
(1.608)\end{array}$ \\
\hline BuyBack & $\begin{array}{c}1.064^{* * *} \\
(0.163)\end{array}$ & $\begin{array}{c}1.175^{* * *} \\
(0.170)\end{array}$ & $\begin{array}{c}1.350^{* * *} \\
(0.201)\end{array}$ & $\begin{array}{c}1.107^{* * *} \\
(0.177)\end{array}$ \\
\hline Firm FE & $\mathrm{Y}$ & $\mathrm{Y}$ & $\mathrm{Y}$ & $\mathrm{Y}$ \\
\hline Country-year FE & $\mathrm{Y}$ & $\mathrm{Y}$ & Y & Y \\
\hline $\mathrm{N}$ & 37209 & 36117 & 25928 & 36116 \\
\hline
\end{tabular}

Notes: This table presents results of panel 2SLS regressions examining the effect of export and import shocks vis-à-vis China on cash holding, controlling for alternative motives for cash holding. Dependent variable is cash holding-to-assets ratio in log. All columns include firm- and country-year fixed effects as well as other firm-level controls such as total sales, operating cash flow, effective tax rate, M\&A, share buyback. Tercile dummy variables included but not reported in this table is based on total assets (column 1), labor productivity (column 2), the share of foreign sales in total sales (column 3 ), and net income per employee (column 4). Standard errors in parentheses are clustered at country-sector-year level. $\left({ }^{*} p<0.10,{ }^{* *} p<0.05,{ }^{* * *}\right.$ $p<0.01$ ) 
Figure 1: Cash and short-term investment in percent of total assets: mean and median.
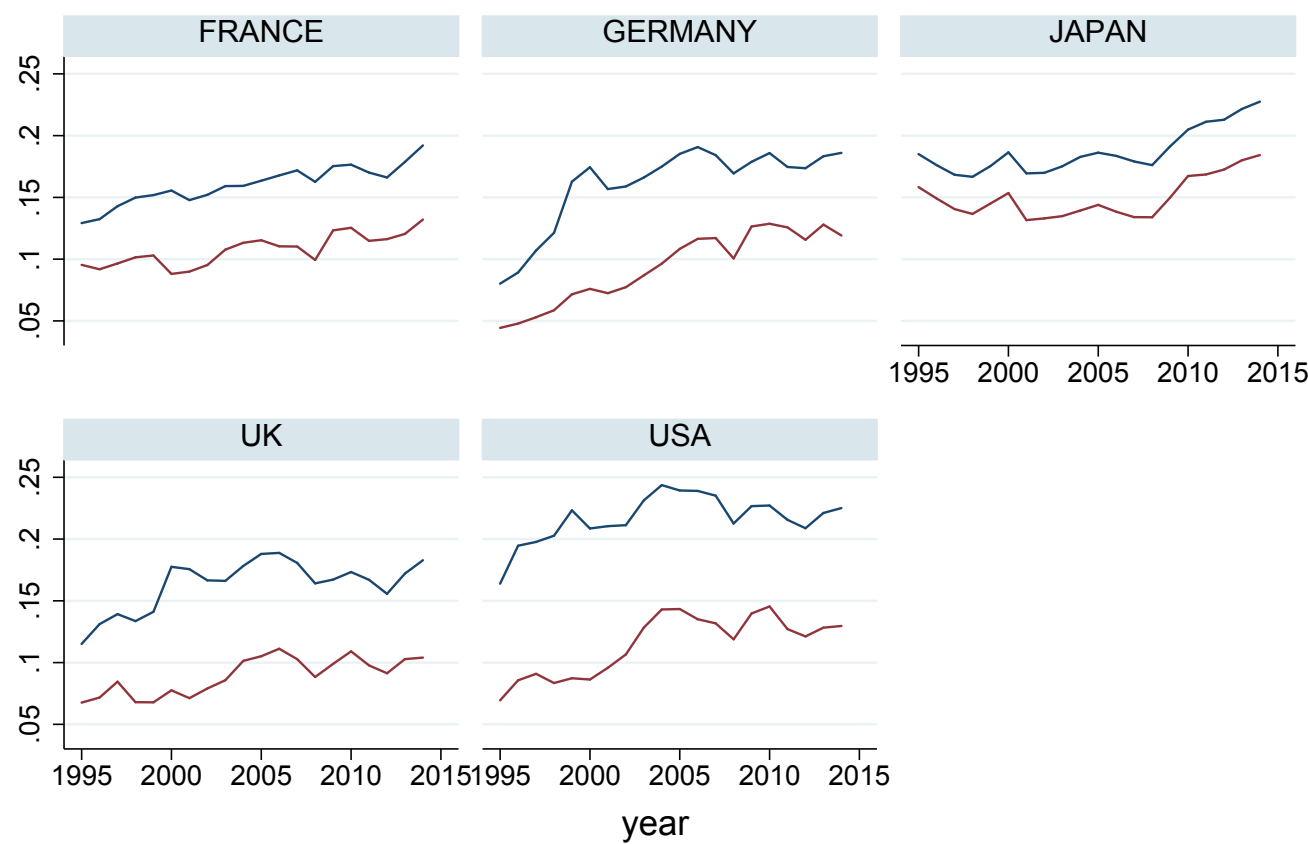

(mean) CashToAssets $\longrightarrow$ (p 50) CashToAssets

Source: Thomson Reuters Worldscope and authors' calculations. Cash to asset ratios are measured by the ratio of cash and short-term instruments to overall book assets. Mean and median cash ratios are calculated for each country year for firms with valid non-missing data. 
Figure 2: Intangible capital as a share of total assets: mean and median.

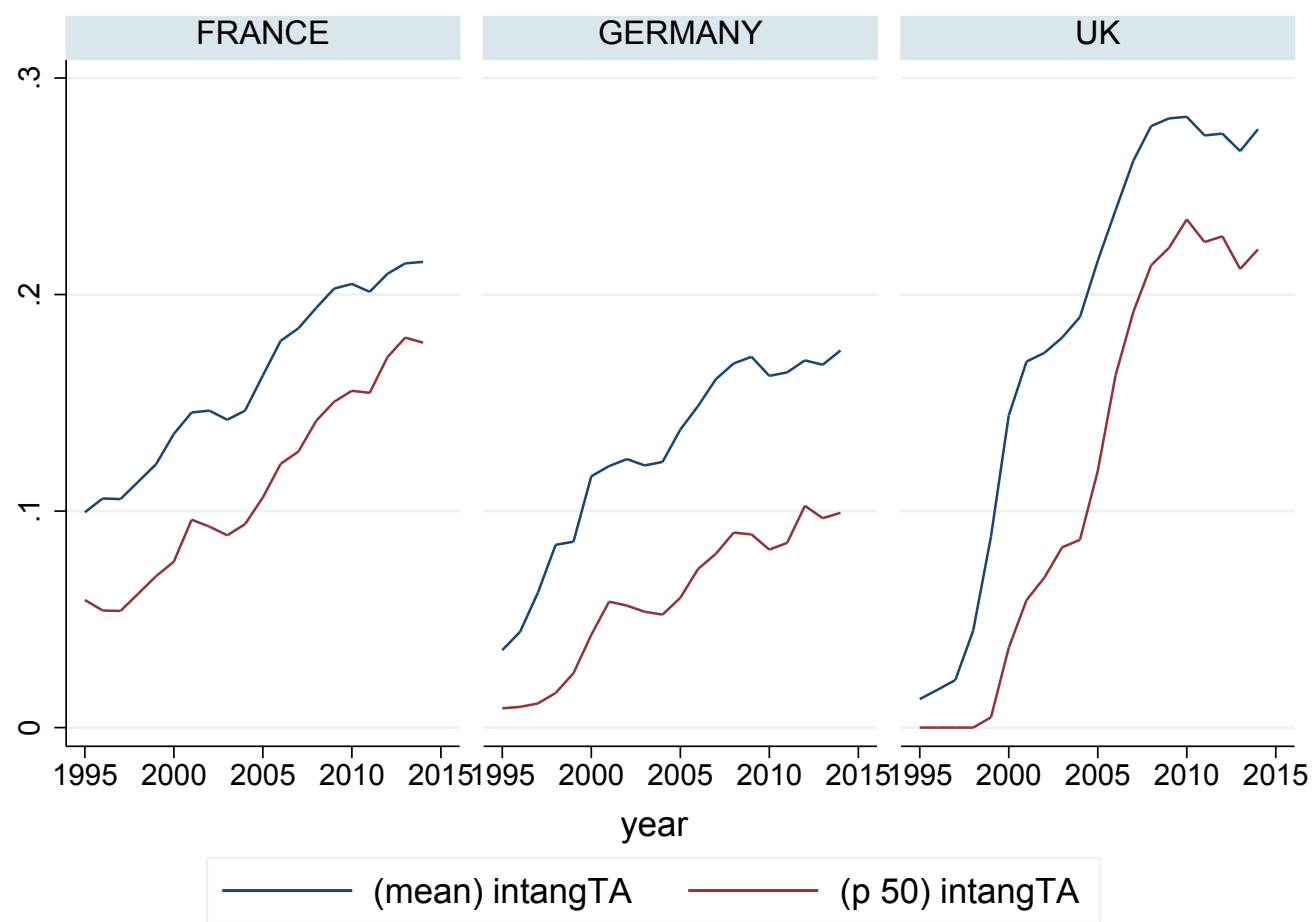

Source: Thomson Reuters Worldscope and authors' calculations. Mean and medians in each country year are calculated for firms with non-missing valid entries for intangible assets. 
Figure 3: cash holdings evolution by innovation intensity.

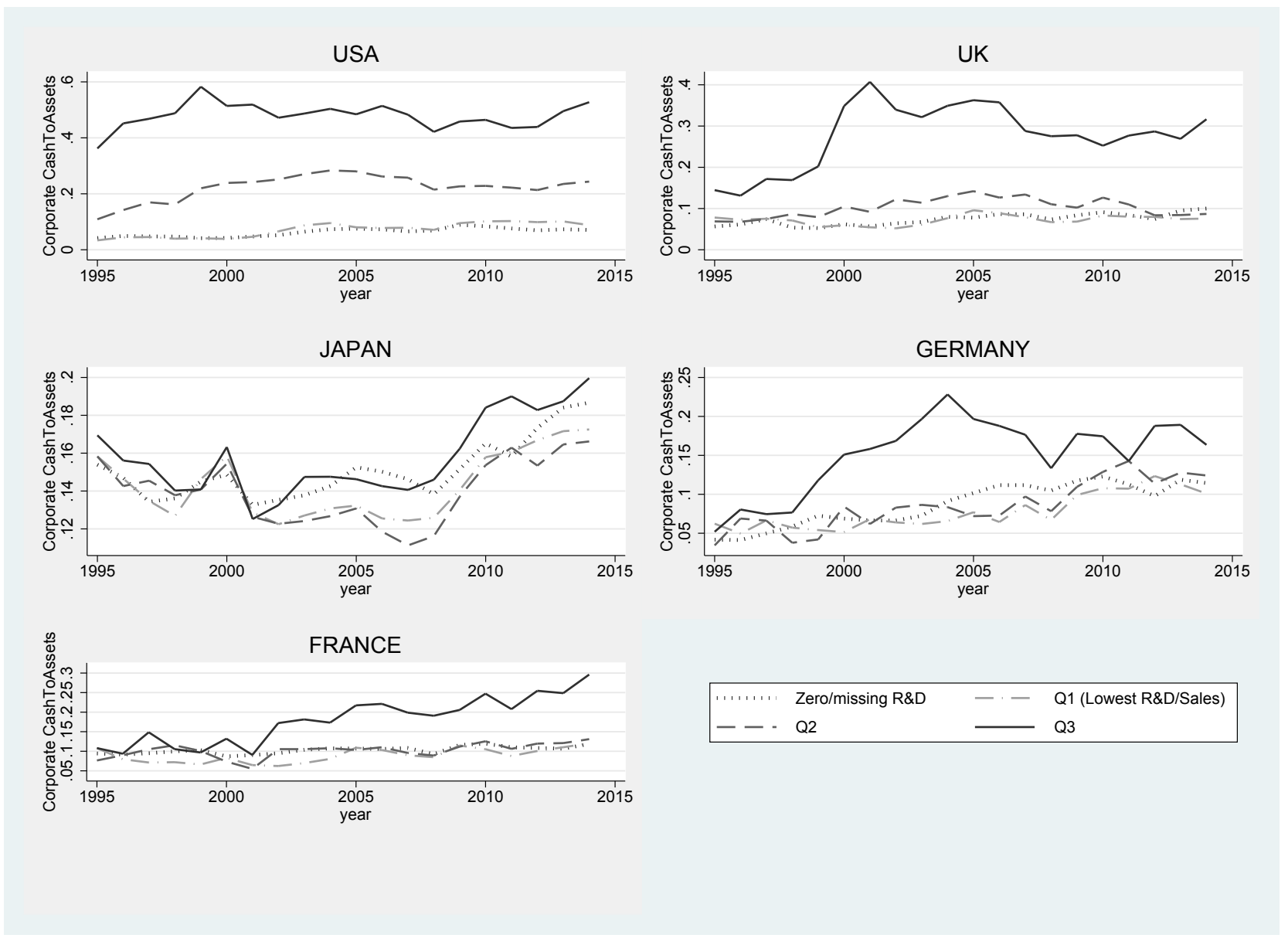

Source: Thomson Reuters Worldscope and authors' calculations. Cash to asset ratios are measured by the ratio of cash and short-term instruments to overall book assets, winsorized at the top and bottom 1 percent. Firms with positive $R \& D$ are sorted into terciles of innovation intensity (measured by $\mathrm{R} \& \mathrm{D} /$ sales ratio) in each country year. The lines indicate the median cash to asset ratio within each tercile of innovation intensity for each country year, and the median cash to asset ratio for firms with zero or missing R\&D data. 
Figure 4: SG\& A evolution by cash-ratio.
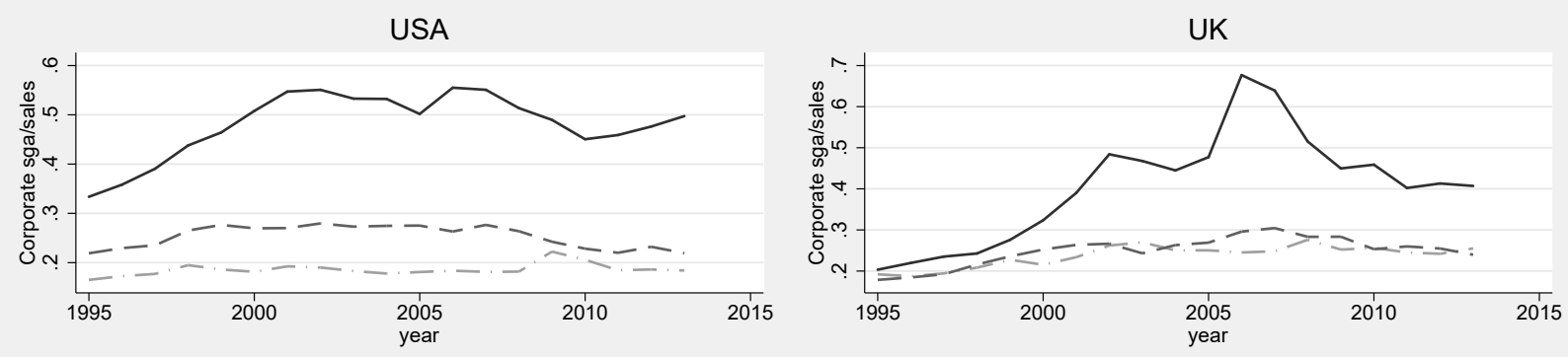

JAPAN
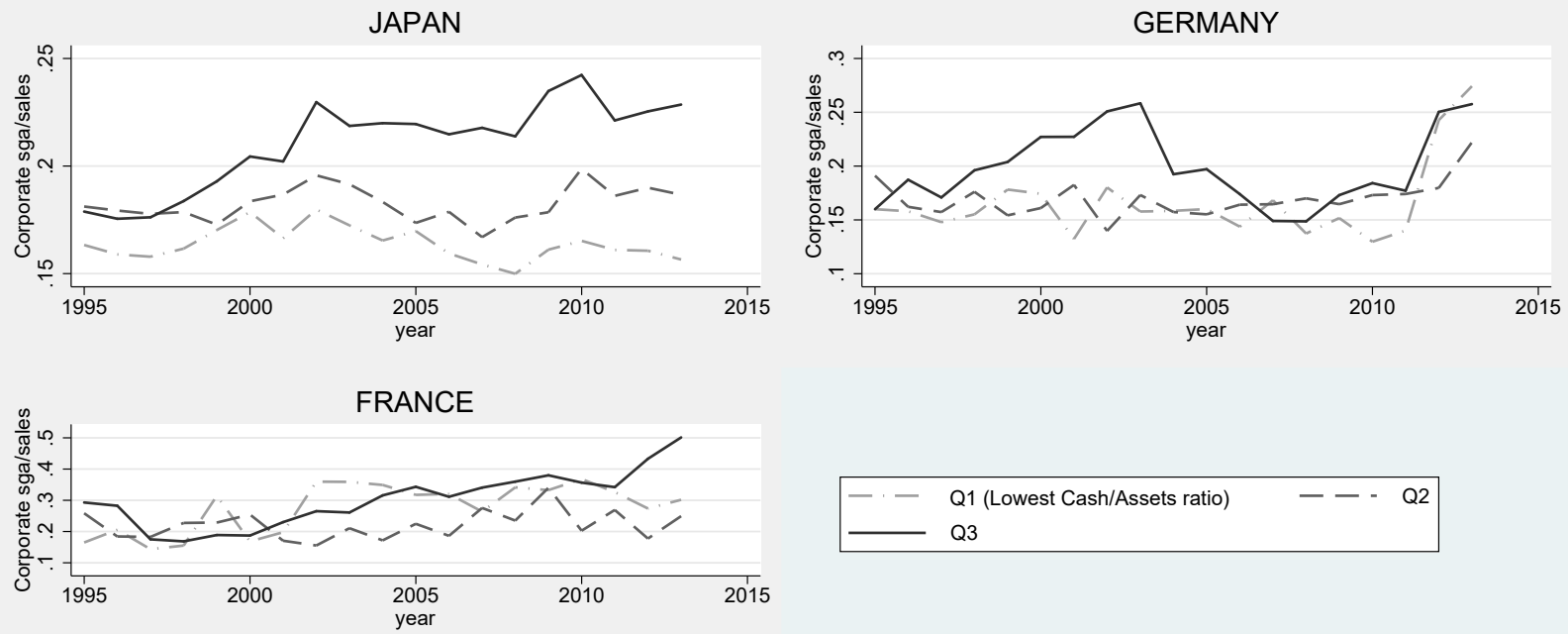

Source: Thomson Reuters Worldscope and authors' calculations. Cash to asset ratios are measured by the ratio of cash and short-term instruments to overall book assets, winsorized at the top and bottom 1 percent. The lines indicate the median SG\& A spending (in percent of sales) within each tercile of cash ratio for each country year. 
Figure 5: Aggregate export shares and cash ratios

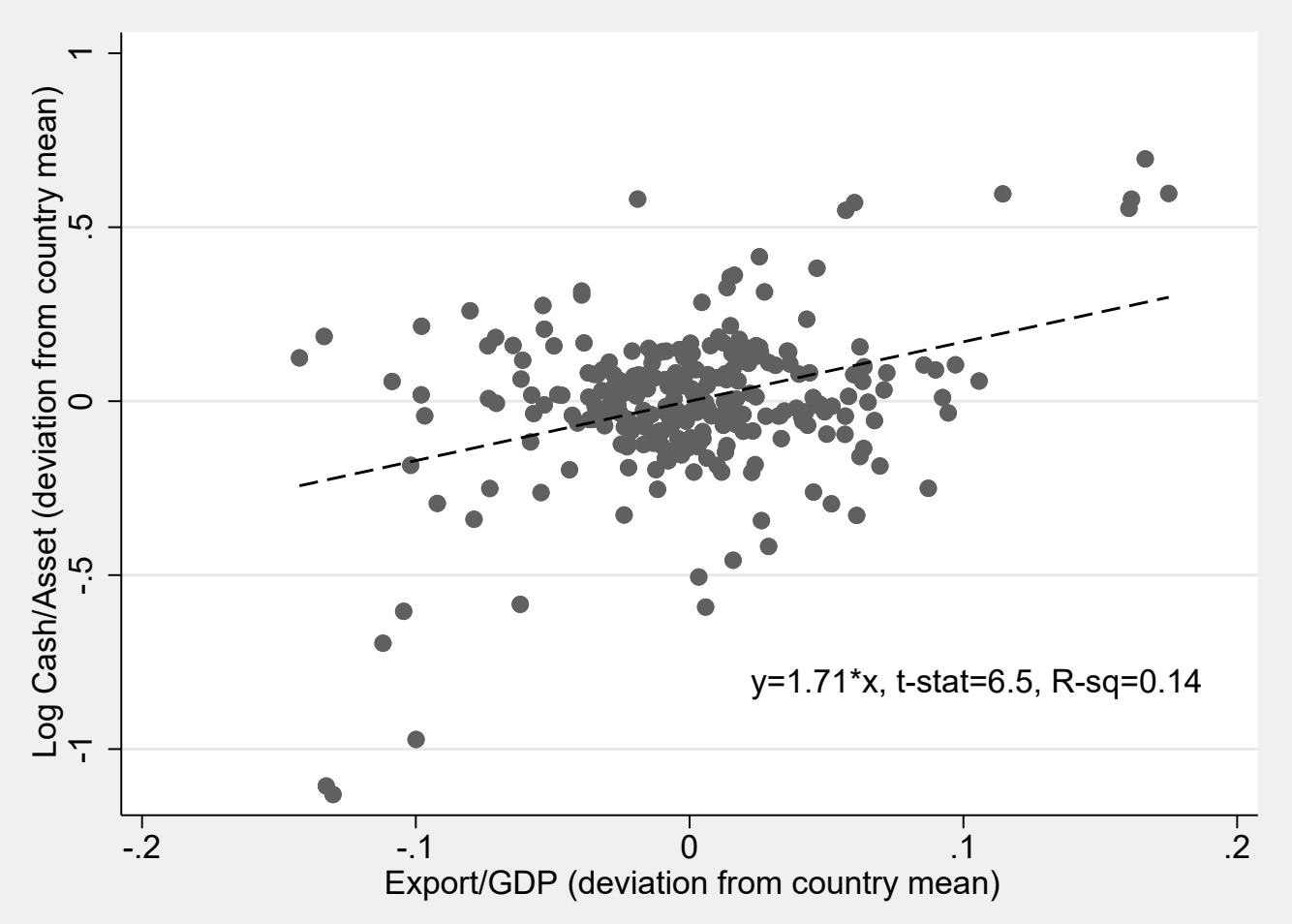

Source: OECD Sectoral Financial Accounts, IFS and authors' calculations. Cash to asset ratios are measured by the ratio of cash and short-term instruments to total financial assets. All values are in deviation from country mean during the period 1995-2015. 
Figure 6: cash holdings evolution by entering cohorts.
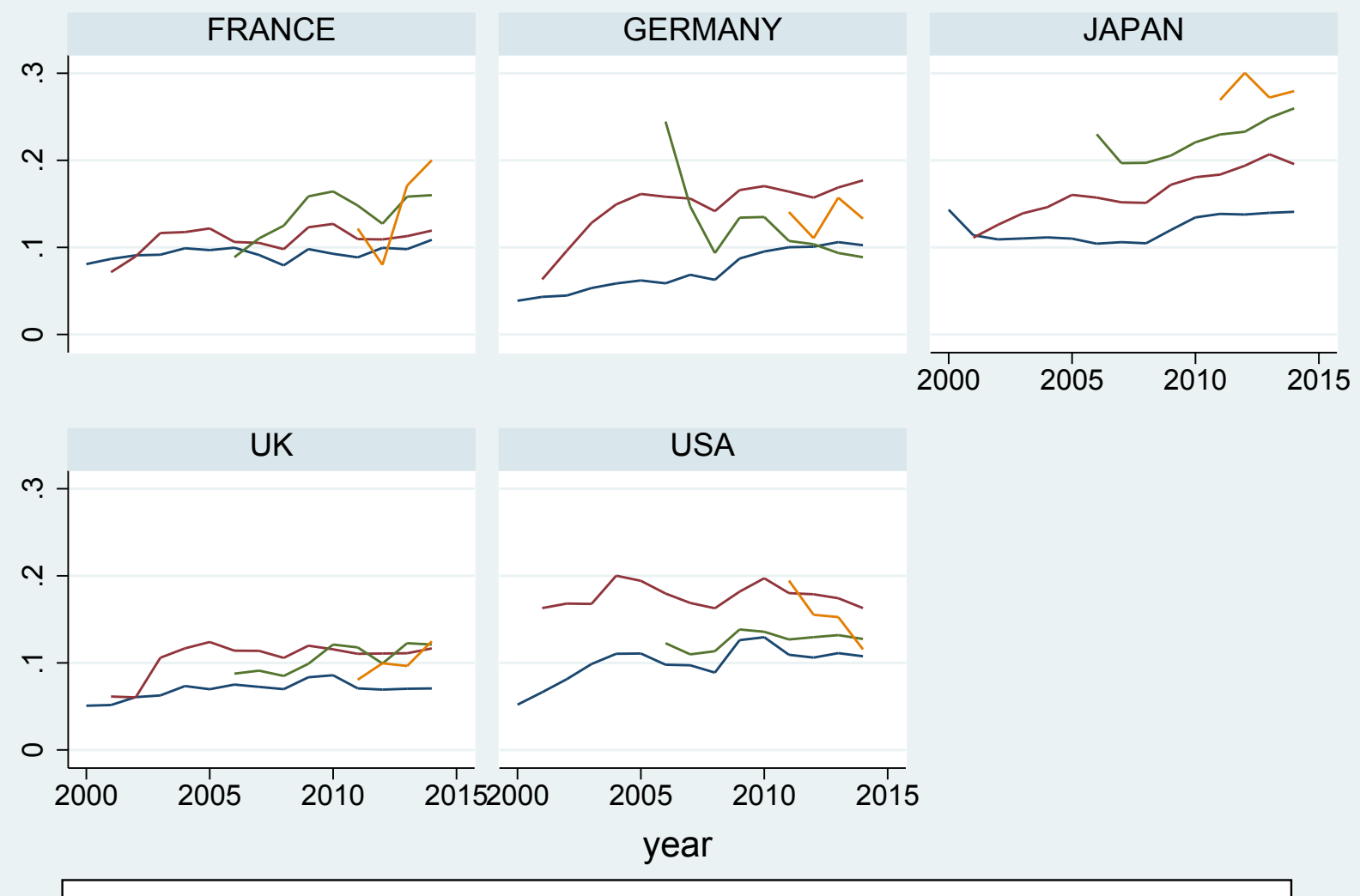

y95

y96_00

y01_05

y06_10

Source: Thomson Reuters Worldscope and authors' calculations. Cohorts are defined as set of firms that appear for the first time in the sample during each consecutive 5-year window. Lines show the median cash to asset ration within each cohort over time. 
Figure 7: Decomposition of aggregate cash ratio to cumulative intensive and extensive margin contribution.
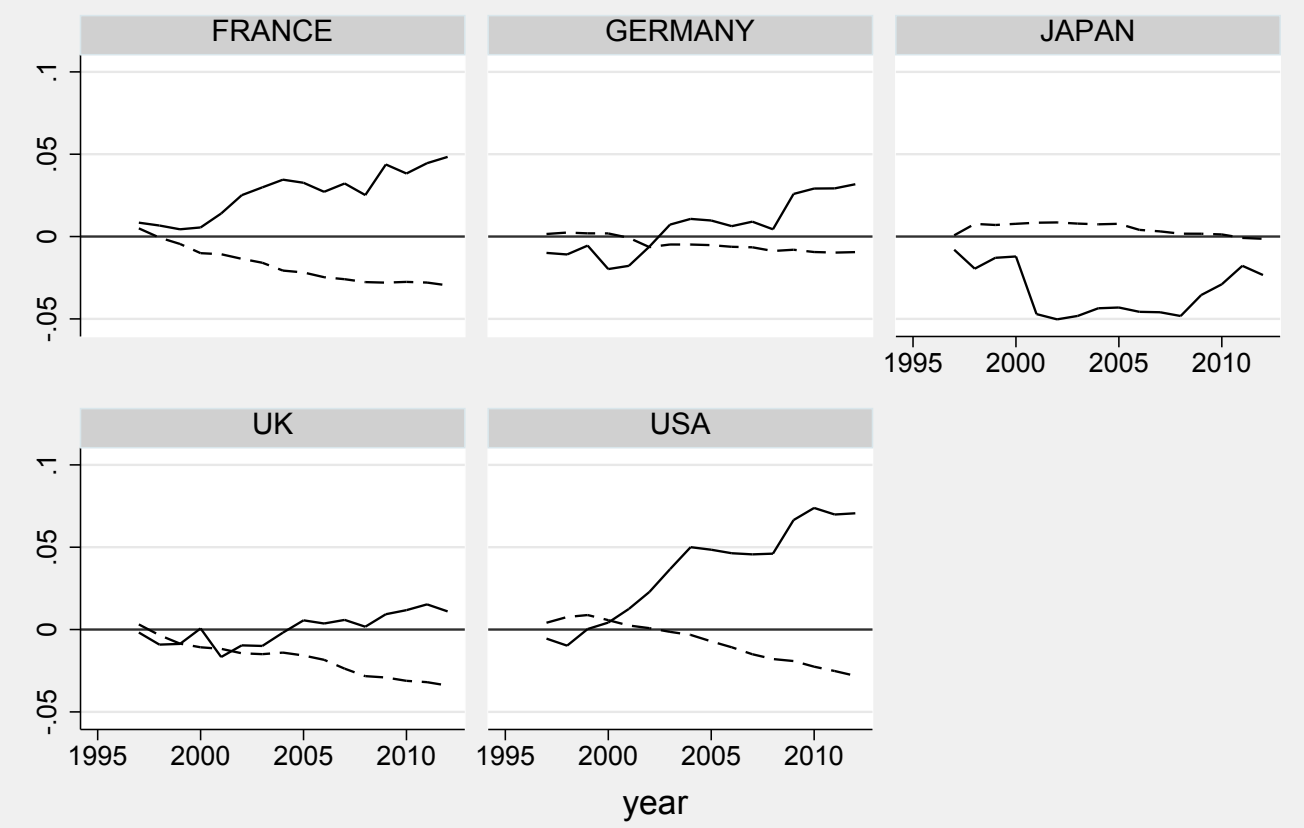

intensive - - - - extensive

Source: Thomson Reuters Worldscope and authors' calculations. The decomposition of total change into intensive and extensive margin contributions follows equation (1) in the text. Cash to assets ratios are winsorized at the top and bottom 1 percent. Only firms with at least 2 consecutive observations of non-missing cash ratios are included. 
Figure 8: Timing of events in the baseline 3-period model.

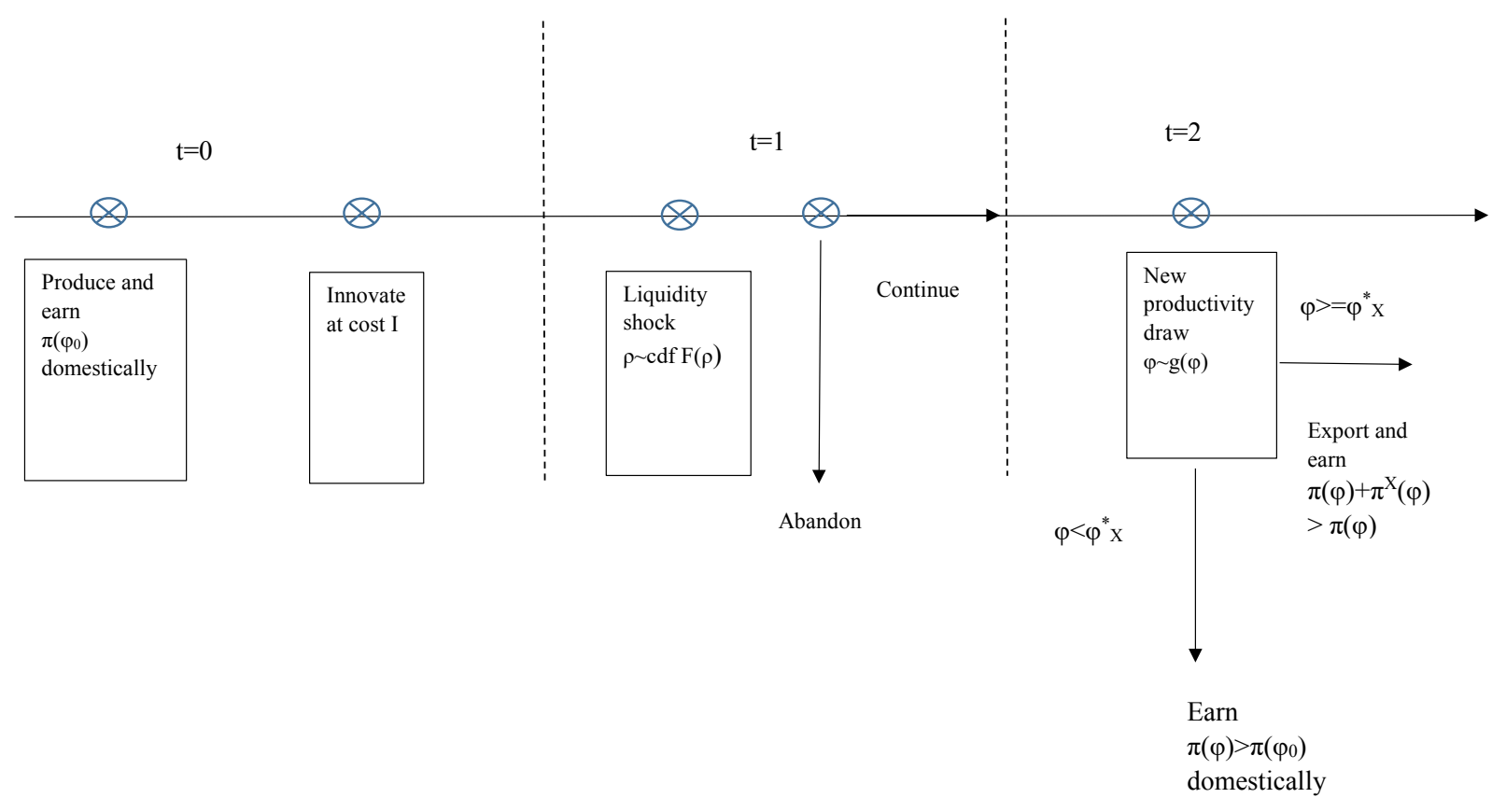


Figure 9: Set of innovating firms and schedule of cash holdings as a function of initial productivity $\phi_{0}$.

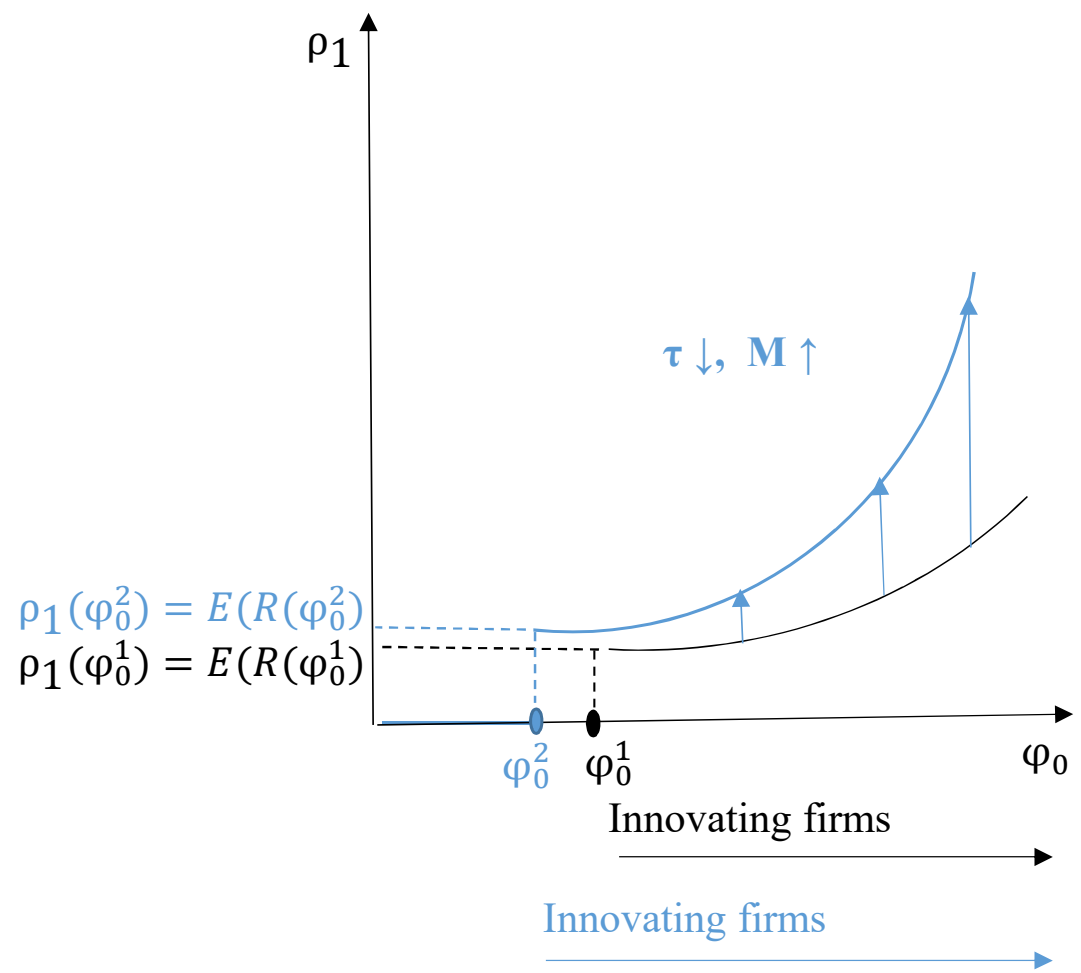

Note: Shift after trade liberalization is sketched in blue. Productivity cutoff for innovators are indexed by 1 and 2 before and after shift. 
Figure 10: The evolving role of China in global trade.
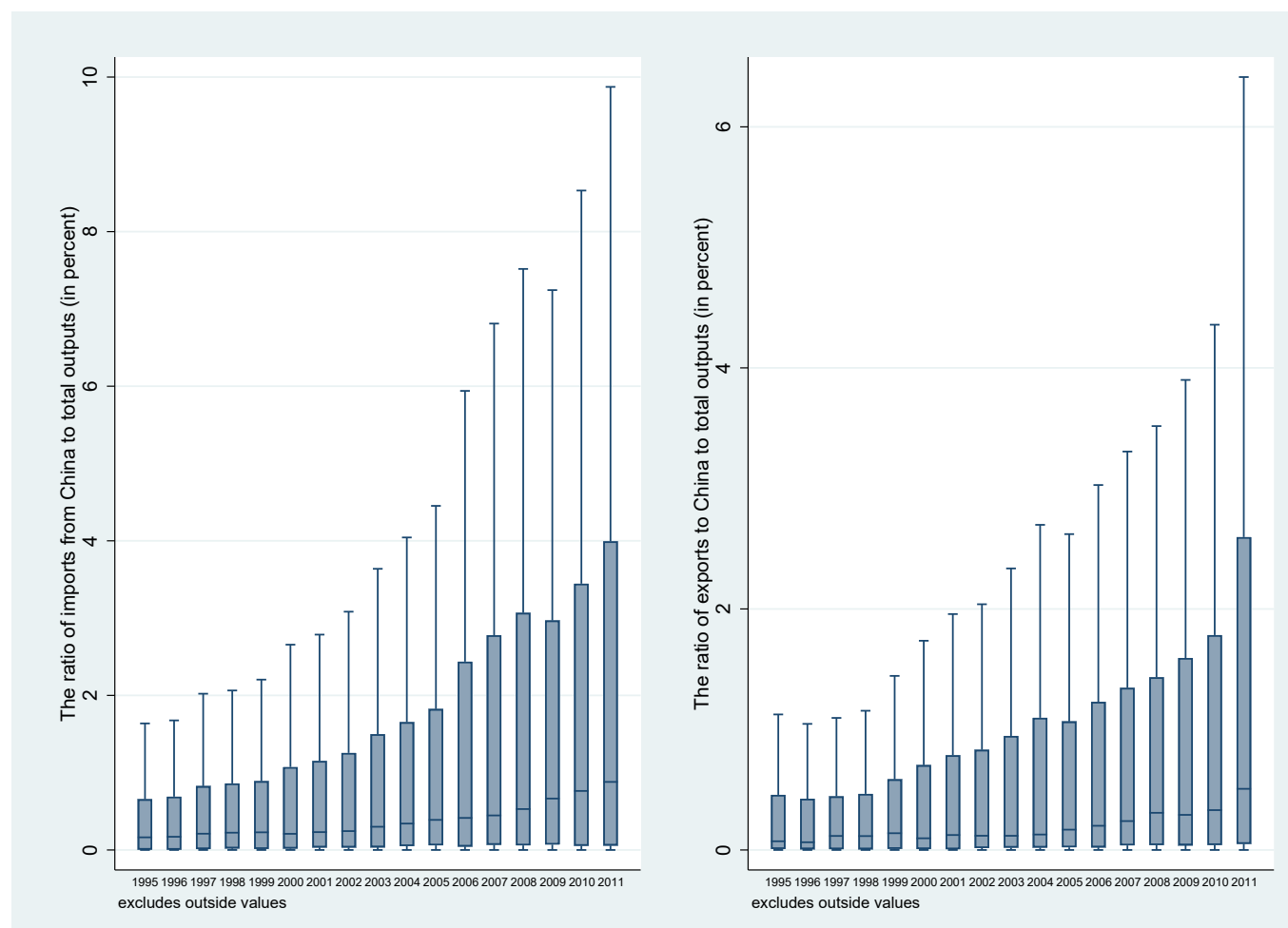

Source: World Input Output Database (WIOD) and authors' calculations; Country-2digit sector level distribution. 
Figure 11: Global tariff liberalization.

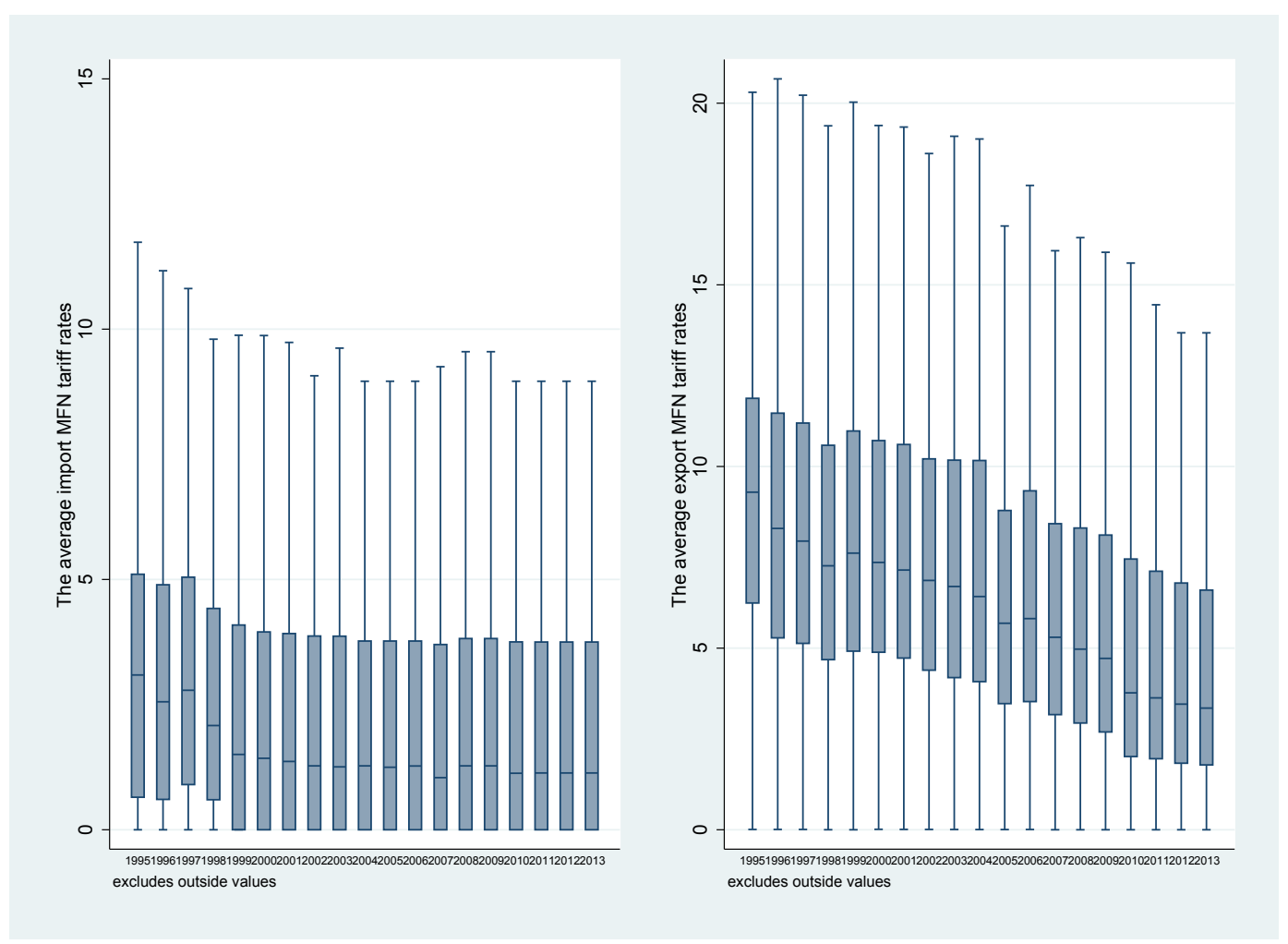

Source: UN Comtrade, TRAINS, and authors' calculations; Country-2digit sector level distribution. 
Figure 12: cash holdings increases with higher export demand, more so for larger firms.

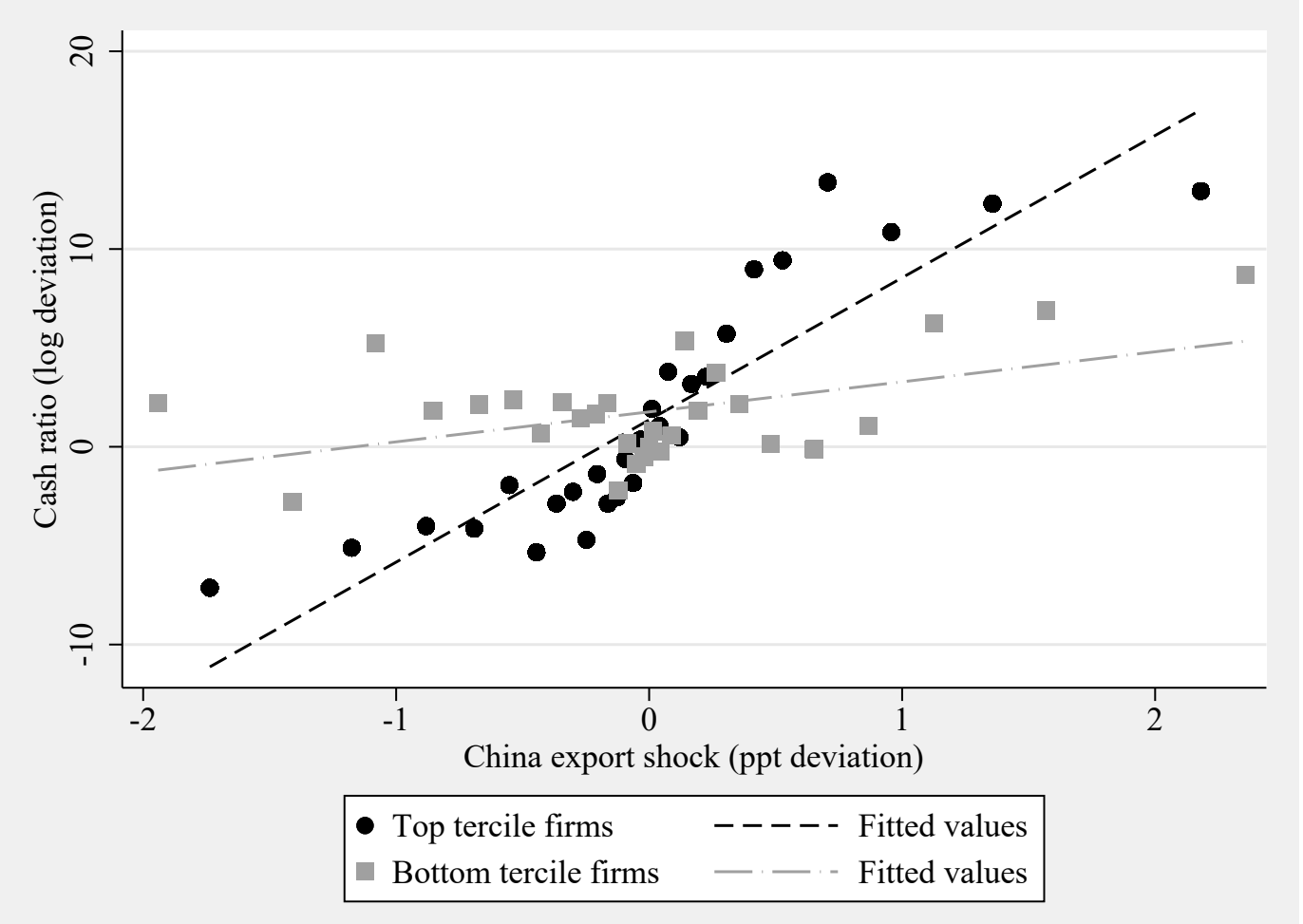

Notes: higher export demand is associated with higher cash holdings, but only significantly so for large firms, i.e. those within the top tercile of asset size distribution of a given country-year. The dots represent the average within each of the 25 quantiles of the China shock (measured as change in export share to China from third countries by industry, weighted by the firm's sales share in its 2 main industries), absorbing the firm fixed effects, plotted against the corresponding quantile-average of log cash holdings, conditional on the firm fixed effect. The conditional correlation is plotted separately for firms in the top and bottom tercile of the country-specific asset size distribution. 


\section{A Appendix}

\section{A.1 Deriving the expected profit from innovating}

\section{A.1.1 Preferences}

As in a one-sector Melitz (2003) model, the preference of a representative consumer (in domestic and export markets) is given by the CES utility function over a continuum of varieties indexed by $\omega$ :

$$
U=\left[\int_{\omega \in \Omega} q(\omega)^{\frac{\sigma-1}{\sigma}} d \omega\right]^{\frac{\sigma-1}{\sigma}}, \sigma>1
$$

where $\sigma$ is the elasticity of substitution between varieties. Denoting the price of each variety as $p(\omega)$, the aggregate price index associated with the aggregate consumption basket of all varieties is then given by the Dixit-Stiglitz aggregator:

$$
P=\left[\int_{\omega \in \Omega} p(\omega)^{(1-\sigma)} d \omega\right]^{\frac{1}{1-\sigma}}
$$

and the demand for each individual variety given by:

$$
q(\omega)=Q\left[\frac{p(\omega)}{P}\right]^{\sigma}
$$

where $Q$ denotes the exogenous real income (in terms of the aggregate consumption basket) of the consumer.

\section{A.1.2 Problem of the firm}

All firms are monopolistically competitive and and hire labor (which is inelastically supplied) to produce a distinct variety $\omega$. Firms differ in their inherent (labor) productivity $\phi$ (or marginal cost $1 / \phi$ ), representing the quantity of outputs (of their variety) produced with each unit of labor. Profit maximization for given wage cost (normalized to one) leads a firm with productivity $\phi$ to set its price according to the mark-up rule:

$$
p(\phi)=\frac{\sigma}{1-\sigma} \frac{1}{\phi}
$$

and realize profits in the domestic markets of:

$$
\pi(\phi)=M \phi^{\sigma-1}
$$

where $M$ is an aggregate demand shifter given by $M=\left(\frac{\sigma}{\sigma-1}\right)^{\sigma-1} \frac{Q P^{\sigma}}{\sigma}$, and taken as given by the firm.

Prior to innovating, all firms are equal and realize the profit level $\pi\left(\phi_{0}\right)=M \phi_{0}^{\sigma-1}$. 
Upon drawing a new productivity level $\phi \geq \phi_{0}$ after innovating, each firm obtains profits in domestic markets given by $\pi^{D}=M \phi^{\sigma-1}>M \phi_{0}^{\sigma-1}$. Moreover, it can export to foreign markets and obtain additional profits $\pi^{X}$ after paying fixed costs $f_{X}$ and incurring iceberg $\operatorname{cost} \tau$ per unit of output sold abroad. Therefore, the firm will only export if and only if:

$$
\pi^{X}(\phi)=M^{X}\left(\frac{\phi}{\tau}\right)^{\sigma-1}-f_{x} \geq 0 \Longleftrightarrow \phi \geq \phi^{*}=\tau\left(\frac{f_{x}}{M_{X}}\right)^{\frac{1}{\sigma-1}}
$$

Ex-ante expected profits of the firm, are then given by:

$$
E(\pi)=\int_{\phi_{0}}^{\infty} M \phi^{\sigma-1} g(\phi) d \phi+\int_{\phi_{X}^{*}}^{\infty}\left[M^{X}\left(\frac{\phi}{\tau}\right)^{\sigma-1}-f_{X}\right] g(\phi) d \phi
$$

which is the equation in the text. We can obtain closed form solution for expected profits by assuming that new productivity draws are distributed according to the Pareto distribution with the cdf:

$$
G(\phi)=1-\left(\frac{\phi_{0}}{\phi}\right)^{\kappa}, \phi \geq \phi_{0}, \kappa>\sigma-1 .
$$

Substituting the density function $g(\phi)=G^{\prime}(\phi)$ into equation (10), we obtain:

$$
E(\pi)=\frac{M \kappa}{\kappa-\xi} \phi_{0}^{\xi}+\frac{\kappa f_{x}}{\kappa-\xi} \phi_{X}^{*}\left(f_{x}, \tau, M^{x}\right)^{-\kappa} \phi_{0}^{\kappa},
$$

which is equation (4) in the text.

\section{A.2 Model extension: external financing and moral hazard}

In this extension of the baseline model, we allow the firm to borrow from outside investors anytime. We now move one step back to the stage after which the firm has survived the liquidity shock but before it draws the new productivity. Prior to drawing the new productivity, the firm can decide to "shirk" and not put its best effort into the project. By doing so, the firm effectively draws its productivity from an alternative Pareto distribution $h(\phi)$ with shape parameter $\lambda>\kappa$, where $h$ has thinner right tail so that the average productivity is lower than under $g$, as more probability mass is concentrated around the lower bound $\phi_{0}$ (see Figure A.1). In addition, since shirking is not verifiable ex-post, the firm gets to keep private benefits $B$ regardless of the actual productivity realization, subjecting the innovation project to moral hazard. ${ }^{21}$. Suppose that the contract with the lender specifies that the firm retains a fraction of its profits in the domestic market, that is, conditional on the productivity draw $\phi$, the firm is paid $R_{f}(\phi)=\eta \pi^{D}(\phi), \eta<1$, while the rest,

\footnotetext{
${ }^{21}$ Moral hazard is essential to understand credit rationing and liquidity demand. In the absence of moral hazard, if the NPV of the project exceeds the liquidity shock and firms can issue claims up to the full value of the NPV, there will be no need for liquidity hoarding as the firm can borrow instantaneously when the shock arrives or issue shares to obtain the funding.
} 
$\pi(\phi)-R_{f}(\phi)=(1-\eta) \pi^{D}(\phi)+\pi^{X}(\phi)$, goes to the lender. Then the firm will put its best effort and not shirk if and only if $E_{G}\left(R_{f}(\phi)\right) \geq E_{H}\left(R_{f}(\phi)\right)+B$ (where the subscripts $\mathrm{G}, \mathrm{H}$ refer to the cdf over which the expectation is taken). This is the case if and only if:

$$
\eta \geq \eta_{\min }=\frac{B / M}{\phi_{0}^{\xi} \xi\left(\frac{\kappa}{\kappa-\xi}-\frac{\lambda}{\lambda-\xi}\right)}
$$

The contractual payment to the firm to ensure its best effort is larger, the larger the private benefit (that it can hide from the lender) and the smaller the difference between the two distributions $G$ and $H$ (captured by the difference between $\lambda$ and $\kappa$ ), that is, the more difficult it is for the lender to distinguish between shirkers and non-shirkers. ${ }^{22}$ On the other hand, the required payment to the firm is lower, the higher its initial productivity, as the expected return from exerting best effort is higher.

Now moving to $t=1$, conditional on being hit by a liquidity shock $\rho$, it immediately follows that the firm should continue whenever $\rho \leq \rho^{1}=E_{G}(\pi(\phi))$, that is when the cost overrun does not exceed the expected profit from continuing the innovation. This is the first-best cutoff that may or may not be chosen by the financial contract in $t=0$.

In $t=0$, assuming the net present value of the innovation project is positive (which effectively introduces a minimum productivity threshold for innovating firms), the firm will want to innovate and require external funding $I$ plus enough liquidity to insure against the liquidity shock in $t=1$. What is the optimal financial contract between the firm and a lender that can be implemented to provide firms with the necessary funding, maximizes the payoff to each party, and is incentive compatible so the firm does not shirk? The timing of the events in this extended version of the model is summarized in Figure A.2.

\section{A.2.1 The optimal contract}

As in Holmström and Tirole (1998), competition among lenders drives their ex-ante expected profit to zero. The optimal financial contract therefore maximizes the payoff to the firm, subject to the break even condition for the lender and the incentive compatibility constraint. The contract is implemented by the liquidity cutoff level $\rho^{*}$, which also corresponds to the firm's level of cash holdings, and the fraction of profit left for the firm $\eta$ :

The optimal contract between the firm and its lender solves the following problem:

$$
\max _{\rho^{*}, \eta} \int_{0}^{\rho^{*}} E_{G}\left(R_{f}\right) f(\rho) d \rho
$$

\footnotetext{
${ }^{22}$ Letting payoff to the firm only depend on profit from domestic sales comes with algebraic tractability without loss of generality. Intuitively, if the return to the firm was a fraction of total profits (domestic and foreign), then more export opportunities will lower the $\eta_{\min }$ necessary to ensure the firm's incentive compatibility and therefore raise pledgable income, which will in turn raise the optimal level of cash holdings $\rho^{*}$ even more.
} 
subject to:

$$
\begin{aligned}
\int_{0}^{\rho^{*}}\left[E_{G}(R)-E_{G}\left(R_{f}\right)-\rho\right] f(\rho) d \rho & =I \\
E_{G}\left(R_{f}\right) & =\eta E_{G}\left(R^{D}\right) \\
\eta & \geq \eta_{\min }
\end{aligned}
$$

The solution of this maximization problem follows closely Tirole (2006). Substituting the lender's break-even constraint (14) and the payout rule (15) into the objective function of the firm, we can reformulate the problem to:

$$
\max _{\rho^{*}, \eta} \int_{0}^{\rho^{*}}\left[E_{G}(R)-\rho\right] f(\rho) d \rho-I=\max _{\rho^{*}, \eta}\left\{E_{G}(R) F\left(\rho^{*}\right)-\int_{0}^{\rho^{*}} f(\rho) d \rho-I\right\}
$$

subject to the break-even condition (14) and the incentive compatibility (IC) condition (16).

As the objective function is the overall return from the innovation project, it is maximized when

$$
E_{G}(\pi) f\left(\rho^{*}\right)-\rho^{*} f\left(\rho^{*}\right)=0,
$$

that is when the cut-off is at the first-best level $\rho^{*}=\rho^{1}\left(\phi_{0}\right)=E_{G}\left(R\left(\phi_{0}\right)\right)$, same as in the baseline model in the main text. However, this cut-off is only feasible if it satisfies the lender break-even constraint (14), in other words, if the pledgable income at first-best cash level $P_{1}$, which is increasing in productivity, is at least as large as the initial outlays $I$ for the lender. This is the case if:

$$
P_{1}\left(\phi_{0}\right)=P\left(\rho^{1}\left(\phi_{0}\right)\right)=F\left(\rho^{1}\right)\left[E_{G}(\pi)-\eta_{\min } E_{G}\left(\pi^{D}\right)\right]-\int_{0}^{\rho^{1}} \rho f(\rho) d \rho \geq I
$$

In this high-productivity scenario, substituting $\rho^{1}$ into the break-even condition (14) delivers the equilibrium $\eta$, which can be shown to fulfill the IC constraint (16). ${ }^{23}$

If condition (19) is not satisfied, then the first-best cut-off cannot be implemented and the optimal liquidity level $\rho^{*}$ is strictly lower than the first best level $\rho^{1}$. This follows immediately from the fact that pledgeable income $P\left(\rho^{*}\right)$ is decreasing in $\rho^{*}$ and that $\rho^{1}$ already maximizes (17). Moreover, as the pledgeable income is decreasing in $\eta$, it follows immediately that the optimal $\eta$, the share of profits left to the firm, is always given by $\eta=\eta_{\text {min }}$, the minimum level to satisfy the IC constraint. The optimal cut-off $\tilde{\rho}$ is then

\footnotetext{
${ }^{23}$ Indeed, because the maximum pledgeable income $P\left(\rho^{1}\right) \geq I$ is evaluated at $\eta=\eta_{\text {min }}$, and the pledgeable income function $P\left(\rho^{1}, \eta\right)$ is decreasing in $\eta$, reducing the pledgeable income from above to equal $I-A$ implies raising $\eta$ above $\eta_{\text {min }}$, introducing slack into IC constraint (16).
} 
pinned down by the break-even condition, that is, it is implicitly given by:

$$
\int_{0}^{\tilde{\rho}}\left[E_{G}(\pi)-\eta_{\min } E_{G}\left(\pi^{D}\right)-\rho\right] f(\rho) d \rho=I
$$

or:

$$
F(\tilde{\rho})\left[E_{G}(\pi)-\eta_{\min } E_{G}\left(\pi^{D}\right)\right]-\int_{0}^{\tilde{\rho}} \rho f(\rho) d \rho=I
$$

Finally, if initial productivity is too low, such that the maximum pledgeable income is less than the initial outlays of the lender, no contract can be written and the firm undertakes no innovation. This is the case if:

$$
P\left(\rho_{0}\left(\phi_{0}\right), \eta_{\min }\right)<I
$$

where $\rho_{0}\left(\phi_{0}\right)$ is the cut-off level that maximizes the pledgeable income to the lender for any given initial productivity of the firm, derived by setting the first derivative of (19) to zero: $\rho^{0}=E_{G}(\pi)-\eta_{\min } E_{G}\left(\pi^{D}\right)<\tilde{\rho}<\rho^{1}$.

Overall, the higher is $I$, the more likely it becomes that the pledgeable income from innovation, for a given level of productivity, is not sufficient to cover the initial outlays. ${ }^{24}$ For a given level of $I$, the level of cash holdings is dependent on the level of productivity of the firm, and we obtain the following results corresponding to the main results in the text. To summarize, the solution to the contract above gives the following decision rule for innovation and optimal level of cash holdings, depending on the initial productivity of the firm:

- If $P_{0}\left(\phi_{0}\right)=P\left(\rho_{0}\left(\phi_{0}\right), \eta_{\min }\right)<I \rightarrow \phi_{0}<\tilde{\phi}_{0}=P_{0}^{-1}(I)$ : low productivity - do not innovate 25

- If $P_{0}\left(\phi_{0}\right)=P\left(\rho_{0}, \eta_{\min }\right) \geq I \rightarrow \phi_{0} \geq \tilde{\phi}_{0}=P_{0}^{-1}(I)$ : sufficient productivity - innovate. Moreover:

- If $P_{0}^{-1}(I) \leq \phi_{0}<P_{1}^{-1}(I)$ : intermediate productivity - innovate and hold cash amount $\tilde{\rho}$;

- If $\phi_{0} \geq P^{-1}(I)$ : high productivity - innovate and hold cash amount $\rho^{1}$.

The schedule for optimal cash holdings as a function of initial productivity is depicted in Figure A.3 and we obtain qualitatively similar results as in the baseline model as follows.

\footnotetext{
${ }^{24}$ In particular, all firms will be able to hold the first-best cash level $\rho_{1}$ if $I \leq P_{1}\left(\phi_{\text {min }}\right)$ and no firm will be able to innovate if $I>P_{0}\left(\phi_{\max }\right)$ if $\phi_{\min }, \phi_{\max }$ are the min-max boundaries of the initial productivity distribution.

${ }^{25}$ Note that this minimum threshold $\tilde{\phi}_{0}$ is above the minimum productivity $\phi_{0}=P_{1}^{-1}(I)$ that guarantees a positive NPV of the innovation project in the first-best and the baseline model, in other words $P_{0}^{-1}(I)>$ $P_{1}^{-1}(I)$, following from the fact that $P_{1}($.$) is strictly larger than P_{0}($.$) for any given level of productivity (in$ turn as maximum pledgeable income is only a fraction of total NPV).
} 
Result 1 extended Only firms above a minimum productivity cutoff will innovate. Innovating firms hold more cash than non-innovating firms. Innovating firms with higher initial productivity hold more cash.

The firm will not be able to obtain funding and innovate if its initial productivity $\phi_{0}$ is below the minimum level at which the maximum pledgeable income is lower than the initial outlays. That is, no innovation and cash holdings for firms with productivity lower than $\tilde{\phi}_{0}=P_{0}^{-1}(I)$, where $P_{0}^{-1}$ is the inverse function of the maximum pledgeable income $P_{0}$, equal to pledgeable income $P\left(\right.$.) evaluated at $\rho^{0}=E_{G}(\pi)-\eta_{\min } E_{G}\left(\pi^{D}\right)<\rho^{1}$.

On the other hand, if productivity is above the upper cutoff $\phi_{\max }$ where $P_{1}\left(\phi_{\max }\right) \geq I$, then the firm is unconstrained in the sense that its pledgeable income at the first-best cash level is enough to cover the initial outlays, and will thus always be able to hold the firstbest cash level $\rho_{1}$ (as in the baseline model).

When initial productivity is in the range $P_{0}^{-1}(I)<\phi_{0}<P_{1}^{-1}(I)$, the optimal cutoff $\rho^{*}$, i.e. the cash holdings of the firm resulting from the optimal contract with the investor will be determined by the break-even condition of the lender:

$$
P\left(\rho^{*}\left(\left(\phi_{0}\right)\right)=F\left(\rho^{*}\right)\left[E_{G}\left(R\left(\phi_{0}\right)-\eta_{\min }\left(\phi_{0}\right) E_{G}\left(R^{D}\left(\phi_{0}\right)\right)\right]-\int_{0}^{\rho^{*}} \rho f(\rho) d \rho=I .\right.\right.
$$

Call the level of the cutoff solving this condition to be $\rho^{*}=\tilde{\rho}$. As in the baseline model, firms with higher productivity hold more cash to withstand a larger liquidity shock, either because they are unconstrained and expect a higher NPV from innovation (if $\phi_{0} \geq \phi_{\max }$ ), or because they are constrained but are able to commit to more pledgeable income (if $\tilde{\phi}_{0}<$ $\left.\phi_{0}<\phi_{\max }\right)$. This relationship is depicted by the solid black curve in Figure A.3.

Result 2 extended Conditional on being an innovating firm, globalization in terms of lower trade costs $\tau$ and/or expanded foreign market size $M^{X}$ increases the level of the firm's cash holdings, that is $\frac{\partial \rho^{1}}{\partial \tau}<0, \frac{\partial \rho^{*}}{\partial M^{X}}>0$. Moreover, more productive firms increase their cash holdings more in response to the same shock than less productive ones.

Recall that cash holdings of the innovating firm equals $\rho^{*}=\rho^{1}=E_{G}\left(R\left(\phi_{0}\right)\right)$ if it has high initial productivity $\phi_{0} \geq \phi_{\max }=P_{1}^{-1}(I)$. In this case, it immediately follows that $\frac{\partial \rho^{1}}{\partial M^{X}}>0$ as larger export markets increase expected profits from innovating by increasing the probability of becoming an exporter (lowering the exporter cutoff $\phi_{X}^{*}$ ) and by increasing profit from exporting conditional on drawing a high enough productivity. If the firm's initial productivity lies in the intermediate range $P_{0}^{-1}(I) \leq \phi_{0}<P_{1}^{-1}(I)$, then by implicit function theorem applied to the optimality condition (22), we have:

$$
\frac{\tilde{\rho}}{\partial M^{X}}=\frac{F(\tilde{\rho})}{f(\tilde{\rho})\left(\tilde{\rho}-\rho_{0}\right)} \frac{\partial E(R)}{\partial M^{X}}>0
$$


and thus, conditional on being an innovator, i.e. on having sufficiently high productivity, the level of cash holdings always increases with higher export markets (or lower trade $\operatorname{costs} \tau$ ). Finally, the first term of $\frac{\partial \tilde{\rho}}{\partial M^{X}}$ is increasing in $\tilde{\rho}$, which in turn is increasing $\phi_{0}$ (per Result 1 above), while the second term corresponds to $\frac{\partial \rho^{1}}{\partial M^{X}}$ and therefore also increasing in $\phi_{0}$. Thus, subject to the same positive export shock, a higher underlying productivity will lead to a stronger boost to cash holdings. This shift is depicted by the blue arrows and associated solid blue curve in Figure A.3.

Result 3 extended Globalization in terms of lower trade costs $\tau$ and/or expanded foreign market size $M^{X}$ reduces the productivity threshold for innovation and thus, for a given distribution of initial productivity across firms, increases innovation activity and the average cash holdings among incumbent firms in the industry.

As discussed in Result 1, the minimum productivity threshold for innovation depends negatively on the level of pledgable income, which in turn depends positively on the exante expected profit from innovating. By raising the returns from exporting for high productivity firms, a decrease in $\tau$ increases ex-ante expected profit from innovating as shown in equations (2) and (4). This increases the cutoff level $\rho^{0}=E_{G}(R)-\eta_{\min } E_{G}\left(R^{D}\right)$ which maximizes the pledgeable income and thus the maximum pledgeable income $P_{0}\left(\phi_{0}\right)$ for any productivity $\phi_{0}$. As more income can be pledged and the pledgeable income schedule shifts up, the minimum productivity level $P_{0}^{-1}(I)$ for firms to obtain funding to innovate is lowered. If the distribution of initial productivity $\phi_{0}$ is taken as exogenous in each industry, lower trade costs/larger export markets increase the share of firms that innovate and, as these firms have higher cash holdings than non-innovating firms by the amount $\rho *$, also increases the average cash holdings in the industry. 
Figure A.1: Distribution of new productivity draw if firm behaves (g) and when it shirks (h).

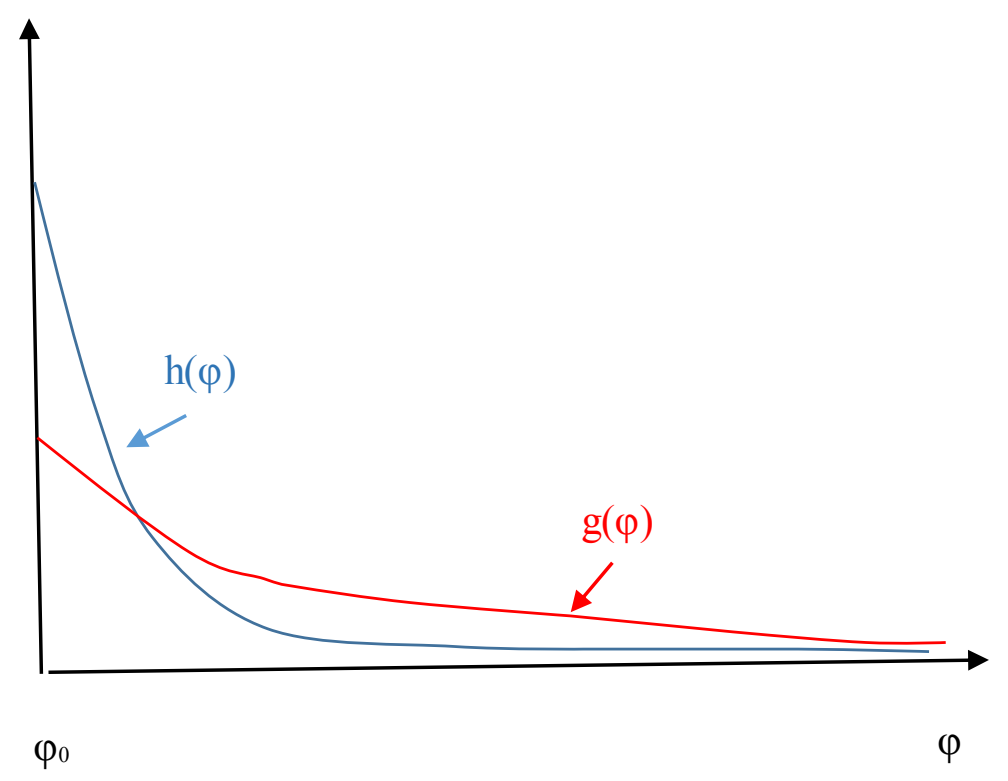

Note: Productivity distribution after innovation and after surviving the liquidity shock. 
Figure A.2: Timing of events in the extended 3-period model.

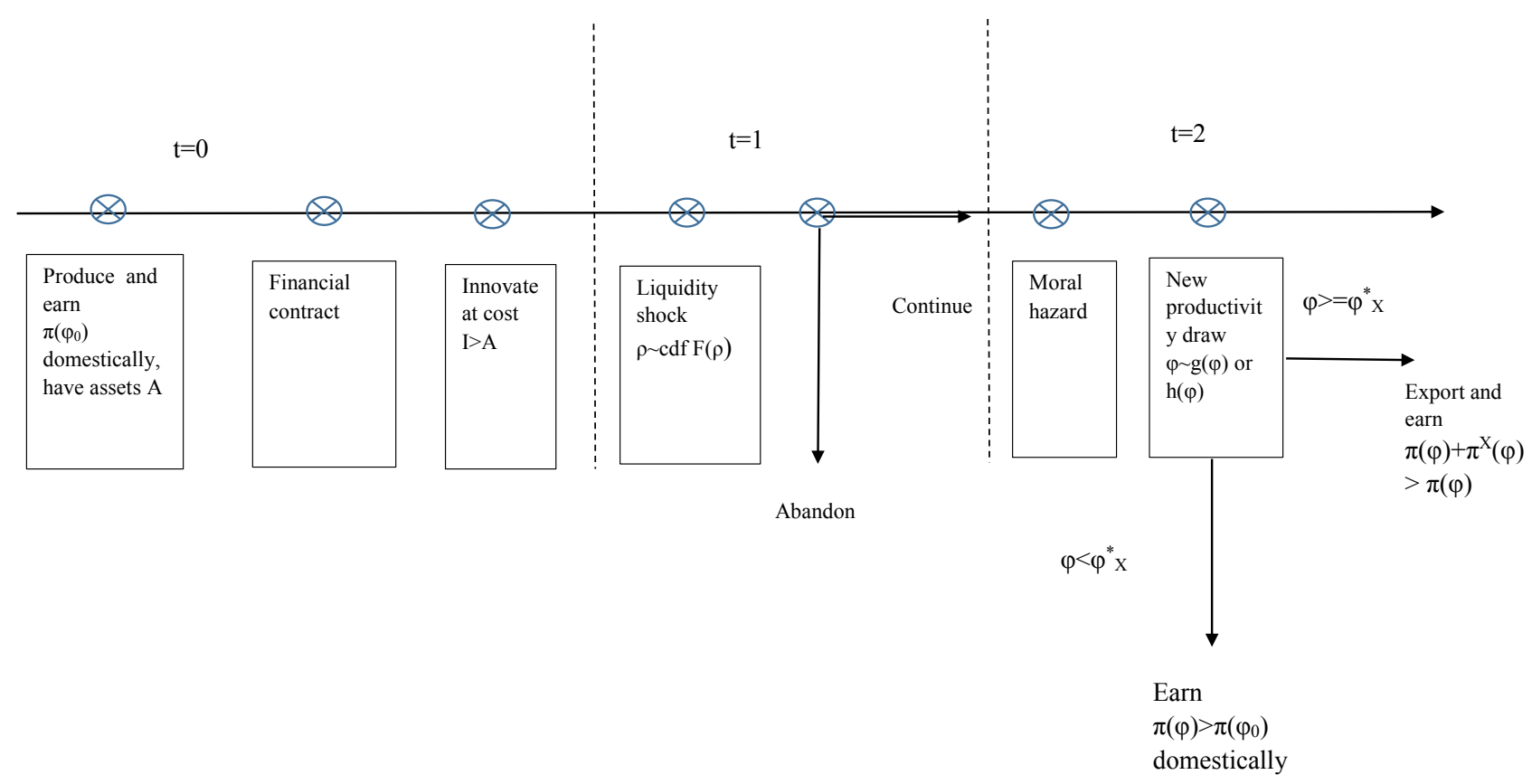


Figure A.3: Set of innovating firms and schedule of cash holdings as a function of initial productivity $\phi_{0}$.

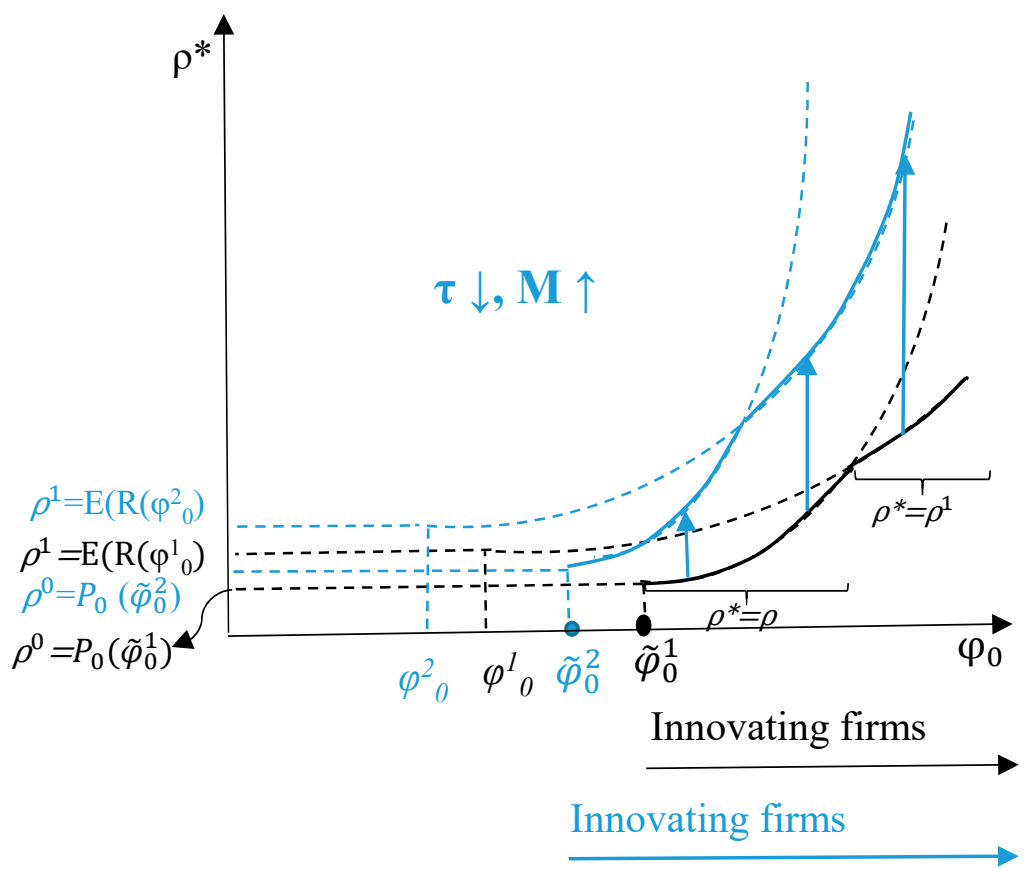

Note: Shift after trade liberalization is sketched in blue. Productivity cutoff for innovators are indexed by 1 and 2 before and after shift.

61 